\title{
Options Trades, Short Sales and Real Earnings Management
}

\author{
Christian Mellado-Cid \\ cmellado@ucsc.cl \\ Universidad Católica de la Santísima Concepción, Chile
}

\author{
Surendranath R. Jory* \\ S.R.Jory@soton.ac.uk \\ University of Southampton, UK
}

Thanh N. Ngo

ngot@ecu.edu

East Carolina University, USA

\footnotetext{
* Corresponding author: Surendranath Rakesh Jory, Southampton Business School, University of Southampton, Room 4065, Building 2, Highfield, Southampton, SO17 1BJ, United Kingdom. Email: S.R.Jory@soton.ac.uk; Tel: +44 (0)23 8059 5923; Fax +44 (0)23 80593844.
}

The authors would like to thank Juan Manuel Garcia Lara (the Editor) and two anonymous referees for helpful comments and suggestions. 


\title{
Options Trades, Short Sales and Real Earnings Management
}

\begin{abstract}
We study the link between measures of stock options' volatility and firms' real earnings management (RM). We hypothesize that RM causes uncertainty in the value of a firm's common stock and, as a result, increases the volatility spread and skew of the firm's options. Spread and skew proxy for investors' uncertainty in the value of the options underlying a stock. Consistent with our hypothesis, we find an association between a firm's use of RM, and the volatility spread and skew in the firm's options, more precisely in its put options. We also study the link between short selling and the extent of RM but do not find a consistent relationship between the two.
\end{abstract}

Keywords: Stock Options; Short Selling; Real Earnings Management; Earnings Quality JEL Classification: G14; M41; D82 


\section{Options Trades, Short Sales and Real Earnings Management}

\section{Introduction}

We study the link between real earnings management (RM) and (i) the volatility in the firm's options and (ii) the extent of short selling in the firm's stocks. We argue that RM causes a firm's true value to deviate from its value reported in the financial statements, which leads to uncertainty among investors and volatile stock prices. The volatility in stock prices causes the price of options on the firm's stock to increase. However, given that RM is more likely to lead to an eventual stock price decline than to an increase, option investors are more likely to take long positions in put options (which gain value with stock price decreases) rather than call options (which lose value when the stock price decreases) to benefit from the uncertainties created by real earnings management. Short sellers, on the other hand, will only benefit from the eventual stock price decline.

Real activities manipulation can be disguised as ordinary business decisions, making it difficult to detect by the average investor. ${ }^{1}$ It involves a firm altering its business operations to inflate reported earnings for a variety of reasons including to meet earnings benchmarks (Gunny, 2010), to avoid reporting annual losses (Roychowdhury, 2006) and violations of debt covenant (Kim, Lisic and Pevzner, 2011), to reach dividend thresholds (Atieh and Hussain, 2012) and to influence credit ratings (Liu, 2017). Examples of RM include aggressive pricing strategies, fire sales of its assets, cuts in real investments and discretionary expenditures, like research and development. The effect of RM can be particularly

\footnotetext{
${ }^{1}$ There are two earnings management categories - i.e. accruals manipulation (AM) and real earnings manipulation (RM). AM does not alter a firm's operations, and occurs when there is a change in a firm's financial reporting choices. For instance, a firm may opt to change its depreciation policy or inventory valuation method simply to depict better earnings figures. However, the current paper's focus does not include AM. Thus, earnings management, real earnings management, real activities manipulations and RM are used interchangeably in the paper unless otherwise specified.
} 
detrimental in the long run as the firm's competitiveness is markedly hampered (Bhojraj et al. 2009). The stock price of such companies is expected to decline, opening up the possibility for short sellers and options traders to capitalize on this.

To profit from an anticipated stock price decline, short sellers borrow shares, sell them and wait for their prices to fall before buying them back to return to the lenders. Similarly, put options enable investors to profit from share price declines, allowing them to sell the shares at a higher price (i.e. the strike price) if the market price falls below it. If long positions in put options are profitable when stock prices decline, then a reverse position in a call option (i.e. a short call) can also be beneficial. If RM causes share prices to decline, then short selling, long positions in put options and short positions in call options would be profitable.

There is, however, no certainty that all RM activities lead to lower stock prices, and not all firms manage earnings to deceive investors. For instance, Gunny (2010) argues that a positive association between RM and operating performance suggests that managers use RM to signal future firm value, and to enhance the firm's reputation and credibility with its stakeholders. The enhanced reputation serves as a platform for the firm to grow. Bhojraj et al. (2009) argue that managing earnings with a view to exceeding analysts' forecasts could yield higher contemporaneous returns that will increase the valuation premium the firm receives in a takeover. The authors caution, nonetheless, against a reversal in future earnings and a downturn in performance following the manipulations. Given the ambiguity in the precise effect of RM on share prices, this uncertainty would feed into options' volatility, which would in turn cause option prices to increase and benefit investors with long positions in the options. The uncertainty, though, would not benefit short sellers. Should the stock price increase, then short sellers would suffer losses. 
Besides, while the two strategies - i.e. shorting shares and buying put options - allow the investor to profit from the falling share prices at suspect firms, they are not perfect substitutes. A put option allows for the protection of downside risk; should exercising the put option lead to a loss, the investor has the choice to forfeit the option. Shorting, on the other hand, exposes the investor to unlimited downside risk as the commitment to buy back the shares is binding irrespective of the price move. Thus, we hypothesize that investors would engage in put options trades rather than shorting the stocks of the firms suspect of real earnings management.

There is not much empirical evidence on the actions of options traders at manipulating firms. Since option markets are quick at incorporating new information into stock prices (Easley, O'Hara and Srinivas, 1993), a study of options' trades will shed light on how investors react to accounting information (Donders, Kouwenberg, and Vorst, 2000). In addition to price changes, the options market allows investors to trade the volatility of a stock. ${ }^{2}$ Thus, unlike shorting, options provide more than one avenue for an investor to profit from anomalous financial reporting. Traders usually refer to their option positions as "long" or "short" volatility. Increases in volatility benefit long positions while decreases benefit short positions. This is important, since if RM causes share prices to diverge from their fundamental values in a significant way and increases share price volatility - Sadka (2007) finds that variations in expected earnings leads to price volatility -, it will feed back positively in option prices. ${ }^{3}$ The magnitude of the price change will depend on the option's "vega". ${ }^{4}$ We hypothesize that option volatility will reflect the anticipated impact of RM.

\footnotetext{
${ }^{2}$ Options traders are likely to benefit from the higher volatility in options' prices induced by real earnings management.

${ }^{3}$ Vuolteenaho (2002), and Callen and Segal (2004) find that earnings news drive equity returns.

${ }^{4}$ Vega shows the effect of a change in stock price volatility on the option price. The higher the effect of RM on the stock price volatility, the greater will be the change in the option price.
} 
Earnings management will cause option traders to revise upward their estimates of the option's volatility, resulting in an increase in its implied volatility, and we test for these changes at earnings manipulating firms.

Our sample consists of US-listed firms covering the period from 1996 to 2011. Consistent with the hypothesis that RM causes uncertainty in stock prices, we document a positive association between a firm's level of real earnings management and the volatility spread and skew of the firm's options, which are two alternative proxies for options volatility. Our findings suggest that RM is associated with stock price declines rather than with stock price increases. We find that higher RM is associated with more open interests in put options, which would suggest that there is a high demand on these firms for put options (which happens on expectations of stock price declines). Consistent with the higher demand for put options, the implied volatility of put options exceeds that of call options at firms using RM.

Conversely, we do not find evidence that short sellers target firms with high levels of RM. This finding could be due to several reasons. Real activities manipulations are often disguised as ordinary business decisions and are, therefore, more difficult to identify, which would deter short sellers from pursuing RM-based trading strategies. Investors may consider other forms of trade (for instance, trading in options) to exploit RM. Additionally, the higher costs (for instance, posting collateral and margin, and the below-market rate received on those deposits) and risks associated with shorting stocks compared to holding put options could explain why short sellers do not trade on RM. Short sellers must maintain margin accounts - the SEC requires short sellers to post up to $50 \%$ of their positions in a margin account - to settle losses as they occur. Shorting also exposes the trader to unlimited losses, which is not the case with long positions in put options. If, contrary to RM expectations, the stock price of the target firm increases, the put option holder loses only the option premium while the short seller's loss is considerably larger. Restrictions imposed by brokerage firms 
and the capital-intensive nature of the margin requirements on short sales mean that shorting is not accessible to all investors (for instance, institutional investors are constrained in their ability to short stocks (see Asquith and Meulbroek, 1995)). ${ }^{5}$ Using options, instead, allows investors to fine-tune the risk level they can afford, and to limit their losses should RM fail to lead to a decline in share prices. Besides, given the higher risks faced by short sellers, it is unlikely that investors will hold their short positions for too long. Options, instead, can be long term, for instance, six or nine months long and some extend for terms up to two years (such as Long Term Equity Anticipation Securities). Consequently, using options to speculate on the long-term effects of real activities manipulations is more realistic.

Since we focus on RM, it is important to note that firms are making greater use of it following the passage of the Sarbanes Oxley Act (Cohen, Dey and Lys, 2008). Thus, postSOX, the preponderance of RM would suggest a stronger association between RM and investors' strategies to benefit from RM during that period. Indeed, we find the association between real earnings management and the measures of option volatility to be positive and statistically significant following the passage of the Act. Conversely, there continues to be no association between RM and short selling in both periods.

The rest of the paper is organized as follows. Section 2 presents the related literature and hypothesis development. Section 3 describes the data and the research methodology. While section 4 discusses the results, section 5 concludes and summarizes the main findings.

\section{Literature Review and Hypotheses Development}

\footnotetext{
${ }^{5}$ Hirshleifer, Teoh and Yu (2011) argue that since it is either harder or more costly to sell a stock short than to go long, arbitrageurs can more easily exploit underpricing than overpricing, which would suggest that short sellers are less likely to trade overpriced stocks due to RM. Richardson (2003) finds that short sellers do not exploit the overvaluation of firms associated with high accruals. Our findings suggest that they do not seem to arbitrage mispricing due to RM either.
} 
Options traders and short sellers are speculators who trade to profit from mispricing (Grundy, Lim and Verwijmeren, 2012), and from their expectations of future stock price changes. They incur hefty costs to test their market sentiments - option traders pay option premiums; short sellers are subject to margin rules, interest on the stock loans as well as reimbursement of all dividends or other distributions paid to the shareholders of the shorted stock. Given the significant transaction costs, we examine the positions they take in the stocks of firms that engage in real earnings management (RM).

Previous studies document that option traders and short sellers will likely trade on earnings-related news and signals. For instance, Amin and Lee (1997) document abnormally high options trading in the days leading to an earnings news release, and report that options traders can anticipate the direction of the price change induced by the earnings. Donders, Kouwenberg and Vorst (2000) find that negative earnings announcements are associated with excess trading volumes in options. Investors trade before the information release and close their positions after the release. The pre-release surge in trading causes abnormal increases in option prices, volatilities and spreads.

The presence of option traders also serves to adjust stock prices promptly following the release of earnings-related news. This is illustrated by the study of Jennings and Starks (1986). The authors examine the stock price adjustment to the release of quarterly earnings using samples of firms with and without listed options. They find that the two samples exhibit different adjustment processes, with the non-options firms requiring substantially more time to adjust. Consequently, options markets improve the dissemination of earnings-related news. The findings of Amin and Lee (1997), Donders, Kouwenberg and Vorst (2000), and Jennings and Starks (1986) call for an analysis of option trades and how they can be driven by the effects of earnings management in share prices. 
Besides the trades of option traders, it is also imperative to study the trades of short sellers as illustrated by the study of Desai et al. (2006). They examine the behaviour of short sellers around earnings restatements. The authors find that short sellers accumulate positions in restating firms several months in advance of the restatement and subsequently unwind these positions after the fall in share price induced by the restatement. They also find that short sellers target firms with higher levels of total accruals prior to restatements. In another related study, Hirshleifer, Teoh and $\mathrm{Yu}$ (2011) find that high-accrual firms are associated with higher short interest, and this association is particularly strong among firms with shares that are easier to borrow. Thus, short sellers pay attention to the information embedded in accruals. However, it still remains to be established whether investors short-sell the securities of firms that engage in RM activities. Therefore, we extend the studies of Desai et al. (2006) and Hirshleifer et al. (2011) to firms that engage in real activities manipulation. However, to do so, we need to establish how investors see through real earnings management (RM).

Disguised as ordinary business decisions, $\mathrm{RM}$ is difficult to detect by the average investor, who is less likely to sell stocks short and/or trade option volatility. Conversely, sophisticated investors would bear the burden of establishing the validity of a company's financial statements and management actions. Kothari et al. (2016) argue that similar investors “....spend considerable resources to analyse not just managers' accrual choices, but also their operational and strategic decisions (p. 560)". Thus, we expect institutional investors, short sellers and option traders with the expertise and means to exploit price inefficiencies to assess the effects of real activities manipulations on stock prices and trade accordingly.

To the degree that the average investors are unable to detect RM, their valuation of the firm would be inaccurate. In the long run though, as the effects of RM unravel, investors would adjust the firm's stock price. Kothari et al. (2016) argue that investors are unlikely to 
correctly anticipate RM; else, they would instantaneously adjust the stock price with no further implication for future stock returns. This lagged response between the time a firm engages in RM and the time when its real effects are reflected in the firm's stock price presents some very sophisticated investors a window of opportunity to exploit the price discrepancy. Our findings rest on the assumption that such investors (option traders in particular) can see through RM and anticipate the price changes.

\section{Option Traders and Real Earnings Manipulation}

A potential reason for deviations in the options' put-call parity is the trading activity of informed investors (Bollen and Whaley, 2004; Garleanu, Pedersen and Poteshman, 2009; Atilgan, 2014). The lower trading costs and higher leverage effects in the options market (Anderson, Reeb, Zhang and Zao, 2013) relative to short selling provide investors with an attractive setting within which to exploit the stock price effects of real activities manipulation. ${ }^{6}$ Consequently, informed traders are likely to exhibit a preference to trade in the options market rather than the stock market (Aragon and Martin, 2012). Cao, Chen and Griffin (2005) test and find evidence to support the hypothesis that the options market has the ability to displace the stock market as the primary place of informed trading and price discovery. This is especially true when information asymmetry is severe.

RM is aimed at facilitating benchmark beating (Gunny, 2010) and influencing share prices (Li, 2010). If this creates additional uncertainties or future stock price drops, they would increase the firm's options implied volatilities. We should also take into account the heterogeneity that exists in investors' processing of earnings-related information, which would exacerbate information asymmetry and, hence, volatility in the financial markets (also

\footnotetext{
${ }^{6}$ Options allow the investor to benefit from the same increases in wealth as the shareholders do but at a fraction of the cost. Investors in options pay only the premium, which is only a fraction of the share price.
} 
see Bhattacharya et al. 2013). Given this, our first hypothesis, stated in null form, is as follows:

H1: There is no relationship between proxies of share price volatility in the options market and real earnings management.

\section{Put versus Call Options}

Option traders can trade both put and call options to exploit stock price volatility. However, if RM causes stock prices to decrease (increase), then traders would benefit from long positions in put (call) options. It is important, therefore, to establish in which direction RM causes share prices to move. The literature on the effects of earnings management on share prices suggests that earnings management is likely to lead to subsequent falls in share prices. For instance, Rangan (1998) and Teoh, Welch and Wong (1998) find that increases in earnings management at the time of an equity offering is associated with a decline in the stock returns in the years following the issue.

While stock price volatility due to RM causes the premiums (i.e. prices) of both call and put options to increase, put options, however, afford investors trading on RM better protection given RM preponderance to cause stock price falls. This proposition is further motivated by the findings of Kim and Sohn (2013). The authors argue that RM increases firms' cost of equity since RM distorts cash flows and, therefore, investors penalise RM firms by lowering their assessment of the firms' future cash flows. They document a direct relationship between firms' cost of equity and RM. As a result, we hypothesize that to benefit from potential price drops, investors would favour long positions in put options over call options. We expect options traders to take long positions in put options (which gain value with stock price decreases) rather than call options (which lose value when the stock price 
decreases) to benefit from stock price volatility due to RM. Given this, our second hypothesis, stated in null form, is:

H2: There is no relationship between the open interests in put options and real earnings management.

\section{Short Sellers and Real Earnings Manipulations}

Fang, Huang and Karpoff (2016) argue that short selling curbs earnings management and improves price efficiency. They find that firms are less likely to manage earnings when they are exempt from the SEC's short-sale price tests. The same firms are more likely to manage earnings when they are not exempt from the short-sale price tests. ${ }^{7}$

Karpoff and Lou (2010) find that short sellers have the ability to detect firms that misrepresent their financial statements. The authors find that firms that misrepresent their accounts are associated with abnormally high levels of short interest. Similarly, Massa, Zhang and Zhang (2015) document a significant and negative association between the threats of earnings management and short selling. In this paper, we also test for the association between short selling and earnings management. However, we differ in the manner we measure earnings management. Fang et al. (2016) and Massa et al. (2015) use discretionary accruals as their main proxy for earnings management; Karpoff and Lou (2010) use SEC

\footnotetext{
${ }^{7}$ Fang, Huang and Karpoff (2016) find that stocks that were exempt from the short-sale price tests between 2005 and 2007 were associated with lower discretionary accruals. The exemption reduced the cost of shorting these stocks and, therefore, it provided short sellers with the necessary incentives to scrutinise the discretionary accruals of the pilot firms. The authors find that upon expiration of the program, discretionary accruals reverted to pre-program levels. All along, non-pilot stocks that were not exempted from the short-sale price tests did not exhibit a decline in discretionary accruals during the pilot period. Thus, absent the incentive (i.e., the reduced cost of shorting due to the exemption), there is no relationship between short selling and discretionary accruals, a finding that is in line with ours.
} 
enforcement actions to identify financial misrepresentations; we, on the other hand, consider firms' usage of real earnings management (RM).

The evidence suggests that short sellers tend to target accruals manipulators (also see Desai et al. 2006 and Hirshleifer et al. 2011). While as yet untested, the relationship between short interests and real activities manipulation is not straightforward. To the extent that short sellers expect real activities manipulation (RM) to lead to lower stock prices, we should find an increase in short interests amongst these firms - i.e. similar to the findings based on accruals management. Conversely, if RM leads to more uncertainty in the fundamental value of the firm, then it will lead to stock price volatility, which would not interest short sellers. Besides, real activities manipulations are often disguised as ordinary business decisions and are, therefore, more difficult to identify, which would deter short sellers from pursuing RMbased trading strategies. Options, on the other hand, is a safer instrument to exploit the price volatility caused by RM. First, there exists a direct association between volatility in share prices and options premiums (or prices). Also, investors in options are not obliged to exercise their options should prices move against expectations. In addition, as discussed earlier, to the extent that there are disagreements on the true nature of RM, volatility observed in the options market would capture the disagreement among investors. Conversely, the number of shares shorted is not a measure of disagreement. Thus, our third hypothesis is:

H3: There is no relationship between short selling and real earnings management.

\section{Data and Research Design}

\subsection{Model}


We run multivariate regressions in which we control for firm and other characteristics that may affect the level of short interest (SHINT), options spread (VSPREAD) and skew $(V S K E W)$. More specifically, we estimate the following model,

$$
\begin{aligned}
Y_{i, t}=\alpha_{0} Y_{i, t-1} & +\alpha_{1} R M_{i, t}+\alpha_{2} \text { AM }_{i, t}+\alpha_{3} \text { PIN }_{i, t}+\alpha_{4} L M C_{i, t}+\alpha_{5} B M_{i, t}+\alpha_{6} R_{i, t} \\
& +\alpha_{7} V R_{i, t}+\alpha_{8} \text { Leverage }_{i, t}+\alpha_{9} \text { Illiquidity }_{i, t}+\alpha_{10} C S_{i, t}+\alpha_{11} P S_{i, t} \\
& +\alpha_{12} \text { Institutional Ownership }_{i, t}+\alpha_{13} \text { Number of Analysts }_{i, t} \\
& +\epsilon_{i, t}
\end{aligned}
$$

where $Y_{i, t}$ represents SHINT, VSPREAD or VSKEW in separate regressions. RM represents real earnings management (i.e. either $R M$ or $R M_{-} P R O D$ or $R M_{-} D I S X$ or $U_{-} R M$ in separate regressions where $R M_{-} P R O D$ represents abnormal production costs, $R M_{-} D I S X$ represents abnormal discretionary expenditure, and $U_{-} R M$ represents unexpected real earnings management). $A M$ represents accruals management. PIN represents the probability of informed trading computed by Venter and De Jongh (2006) and is available from Professor Stephen Brown's website (Brown and Hillegeist, 2007). ${ }^{8} L M C_{i, t}$ represents the natural logarithm of market capitalization of firm $i$ in quarter $t . B M_{i, t}$ is the book-to-market ratio calculated as the common value of equity divided by market capitalization. $R_{i, t}$ is the monthly return over the window $(-12,-2)$ about quarter $t . V R_{i, t}$ is the standard deviation of the market model residuals using daily returns over a one-year window ending one month prior to quarter $t$. Leverage Levit $_{\text {is }}$ the ratio of total liabilities to total assets. Illiquidity $y_{i, t}$ is the daily ratio of absolute stock $i$ return to its dollar volume, averaged over a year ending one month prior to quarter $t$ (similar to Amihud, 2002). $C S_{i, t}$ and $P S_{i, t}$ are the average proportional bid-ask spreads of calls and puts, respectively. Institutional ownership represents

\footnotetext{
${ }^{8}$ http://scholar.rhsmith.umd.edu/sbrown/pin-data
} 
the percentage of the shares outstanding held by institutional owners as reported in the Thomson Financial database. The number of analysts is obtained from the IBES database.

The choice of the independent variables follows Desai et al. (2006), and Hirshleifer et al. (2011). To account for investors targeting overpriced stocks, we include $R$. Similarly, investors' decisions to trade depend on the stock's liquidity. Investors also target growth stocks, which are associated with lower values of $B M$. As options' prices are directly proportional to the volatility in the stock price, we include $V R$ in the regression, which represents the residual standard deviation from the market model. Investors in put options and short sellers target firms closer to insolvency, which we proxy using the debt ratio. Additionally, investors follow analysts' recommendations and we control for the number of analysts in the regression.

Hirshleifer et al. (2011) document a positive association between SHINT and AM. Their results suggest that the extent of short arbitrage depends (i) on the availability of loanable shares and (ii) the size of the firm, and (iii) the ease with which its shares can be traded (for instance, short arbitrage is easier for NYSE firms as opposed to NASDAQ ones). They use institutional ownership as a proxy for the number of loanable shares. Finally, information asymmetry causes informed traders to speculate using options (Easley, Hvidkjaer and O'Hara, 2002), leading to a rise in the option volatility measures. We control for these variables in the regression.

Endogeneity - There are at least two potential sources of endogeneity in estimating equation (1). The first source is the dynamic aspect of the relationship between the dependent variables and real earnings management. For instance, past levels of options trading may affect the current level of RM, and managers of firms that are the targets of options investors may engage in RM to try to reverse their poor performance and fight back the negative sentiment 
toward their stock. Second, both the level of options trading in a company's shares and RM can be jointly affected by unobserved heterogeneity such as the regulatory environment and corporate governance factors. To address issues of endogeneity, we employ generalized method of moments regressions (GMM) and three-stage least squared regressions (also see, Kang and Sivaramakrishnan, 1995). We repeat the analyses using ordinary least squares (OLS) regressions as robustness checks and their findings are described in footnote $19 .{ }^{9}$

Generalized Method of Moments (GMM) Regressions - To account for the potential dynamic relationship between $Y$ and $R M$ in equation (1), we estimate a dynamic panel data model (which is an augmented version of Arellano and Bond (1991)) ${ }^{10}$. This procedure allows us to account for the potential effect of past levels of the dependent variable on current levels of $R M$, and at the same time controls for unobserved heterogeneity using firm fixed effects (Wintoki, Linck and Netter, 2012). The GMM procedure involves the inclusion of two lags of (past) $Y_{i, t}$ in the regression equation, followed by the use of lags of $Y_{i, t}$ and $R M_{i, t}$ (and other firm characteristics) from time $t-3$ and $t-4$ as instruments for the level of $R M$ at time $t$. The assumption is that the firm's past levels of $Y_{i, t}$ and $R M_{i, t}$ (and other firm's historical characteristics) are important determinants of the firm's current level of real earnings management.

Three-Stage Least Squared Regressions - Separately, and to account for the possibility that both the dependent variable and $R M$ can be jointly affected by unobserved heterogeneity, we employ a three-stage least squared regression to simultaneously estimate both the levels of $Y_{i, t}$ and $R M_{i, t}$ in equation (1). Differing from the two-stage least squared approach, the approach used in this paper accounts for the contemporaneous correlation among the error

\footnotetext{
${ }^{9}$ Our findings are robust to regression methods (OLS, GMM and 3SLS) and to various subsamples.

${ }^{10}$ Also see Arellano and Bover (1995), Blundell and Bond (1998), and Bond (2002).
} 
terms between the equations. While the three-stage least squared regression accounts for unobserved heterogeneity, which is time-invariant, it however fails to account for the dynamic aspect of the relationship between $Y_{i, t}$ and $R M_{i, t}$ (as in the GMM approach).

\subsection{Description of Variables}

\subsubsection{Short Interest, Volatility Spread and Volatility Skew}

Following Asquith, Pathak and Ritter (2005), we calculate short interest (SHINT) as the number of shares shorted in each month scaled by the number of shares outstanding reported in the Center for Research in Security Prices (CRSP) database. SHINT per quarter represents the average of the monthly short interests in the quarter.

The theory and empirical evidence suggests that options' volatility spread (VSPREAD) and equity returns are significantly related (Bollen and Whaley, 2004; Ofek, Richardson and Whitelaw, 2004; Garleanu et al. 2009; Cremers and Weinbaum, 2010). The relationship holds particularly true during earnings seasons (Jin, Livnat and Zhang, 2012; Atilgan, 2014). We use VSPREAD to test whether options traders target firms with higher levels of real activities manipulation (RM). Following Jin et al. (2012) and Atilgan (2014), we measure VSPREAD as the difference between the implied volatility of a put option and a corresponding call option matched on strike price and maturity date. We obtain data on implied volatilities from OptionMetrics. Following Atilgan (2014), the weighted average volatility spread for stock $i$ on day $t$ is defined as follows:

$\operatorname{VSPREAD} D_{i t}=\sum_{j=1}^{N_{i t}} w_{j t}\left(\right.$ IVput $\left._{j t}-I_{\text {V call }}\right)$,

where $j$ is the pair of put and call options with the same strike price and expiration date written on stock $i, N_{i t}$ is the number of options pairs on stock $i$ on day $t$ and $w_{j t}$ is the weight calculated as the ratio of the open interest of put and call options at a given strike price 
divided by the total open interest of put and call options at all strike prices for stock $i$ on day t. $I V_{j t}$ is the option's implied volatility. Based on equation (2), excess demand for put options - consistent with investors anticipating the detrimental effects of real activities manipulations - will lead to higher volatility spreads.

We also calculate the volatility skew $(V S K E W)$, which is another contributor to shortterm stock price movements. Following Jin et al. (2012), we measure VSKEW as the difference in the implied volatility between out-of-the-money (OTM) put options (IVOTMput) and at-the-money (ATM) call options (IVATMcall):

VSKEW $_{i t}=$ IVOTMput $_{j t}-$ IVATM $_{\text {call }}$. $_{\text {. }}$

We consider all call options with a delta in the range of $[0.4,0.7]$ and retain the one closest to 0.5 as IVATMcall. ${ }^{11}$ From the set of put options with a delta in the range of [-0.45, $-0.15]$, we retain the one closest to -0.3 as IVOTMput. VSKEW is the difference between IVOTMput and IVATMcall. Expectations of impending falls in share prices due to real activities manipulations will lead to increases in the implied volatilities of the put options and, therefore, increases in VSKEW.

\subsubsection{Real Activities Manipulation}

Roychowdhury (2006) constructs three measures of real activities manipulation, i.e. the abnormal cash flows from operations, abnormal discretionary expenses, and abnormal production costs, which have been used extensively in studies of RM (for instance, Cohen, Dey and Lys, 2008, Cohen and Zarowin, 2010 and Zang, 2012). Zang (2012) though cautions against the use of abnormal cash flows and finds that the use of abnormal discretionary

${ }^{11}$ Delta refers to the change in the options price following a change in the stock price. 
expenses $\left(R M_{-} D I S X\right)$ and production costs $\left(R M_{-} P R O D\right)$ is less ambiguous. Consequently, we use the latter two variables in the paper.

To estimate the normal level of production costs, we use the following model:

$\operatorname{PROD}_{i, t} / A_{i, t-1}=\beta_{0}+\beta_{1}\left(\frac{1}{A_{i, t-1}}\right)+\beta_{2}\left(\frac{\text { sales }_{i, t}}{A_{i, t-1}}\right)+\beta_{3}\left(\frac{\Delta \text { Sales }_{i, t}}{A_{i, t-1}}\right)+\beta_{4}\left(\frac{\Delta \text { Sales }_{i, t-1}}{A_{i, t-1}}\right)+\mu_{i, t}$,

where $P R O D_{i, t}$ is the sum of the cost of goods sold in quarter $t$ and the change in inventory from quarter $t-1$ to $t ; A_{i, t-1}$ is the total assets of firm $i$ in quarter $t-1$; Sales $_{i, t}$ is the net sales of firm $i$ in quarter $t$; and $\Delta$ Sales $_{i, t}$ is the change in net sales of firm $i$ from quarter $t-$ 1 to $t$. The abnormal level of production cost $\left(R M_{-} P R O D\right)$ is measured as the residuals from equation (4) $\left(\mu_{i, t}\right)$. The higher the residuals are, the larger the amount of abnormal production costs is.

We estimate the normal level of discretionary expenditure using the following model,

$$
\frac{\operatorname{DISX}_{i, t}}{A_{i, t-1}}=\gamma_{0}+\gamma_{1}\left(\frac{1}{A_{i, t-1}}\right)+\gamma_{2}\left(\frac{\text { Sales }_{i, t-1}}{A_{i, t-1}}\right)+e_{i, t}
$$

where $D I S X_{t}$ is the discretionary expenditures (i.e. the sum of $\mathrm{R} \& \mathrm{D}$, advertising, and SG\&A expenditures) of firm $i$ in quarter $t ; A_{i, t-1}$ is the total assets of firm $i$ in quarter $t-1$; and Sales $_{i, t}$ is the net sales of firm $i$ in quarter $t .^{12}$ The abnormal level of discretionary expenditures is measured as the estimated residuals from the regression $\left(e_{i, t}\right)$.

Equations (4) and (5) are estimated cross-sectionally for each industry-quarter with at least 15 observations. We estimate these equations using the whole universe of firm-quarter

\footnotetext{
${ }^{12}$ R\&D refers to Research and Development Expenses; and SG\&A refers to Selling, General and Administrative Expenses.
} 
observations in the Compustat Quarterly database to derive the normal levels of production costs and discretionary expenses. ${ }^{13}$

The abnormal production costs $\left(R M_{-} P R O D\right)$ and abnormal discretionary expenses $\left(R M_{-} D I S X\right)$ are aggregated into a single proxy that represents total real activities manipulation $(R M)$ as follows:

$R M_{i, t}=R M_{-} P R O D_{i, t}+R M_{-} D I S X_{i, t}$

The higher the value of this aggregate measure - i.e. $R M$ - the more likely the firm manipulates real activities. ${ }^{14}$

We also calculate $U_{-} R M$ - i.e. the unexpected level of real earnings management following Zang (2012). For robustness checks, we also present findings based on accruals management $(A M)$, which is a product of the modified Jones' (1991) model (Dechow, Sloan and Sweeney, 1995). ${ }^{15}$

\subsection{Data and Descriptive Statistics}

We obtain the options data from the Ivy DB OptionMetrics Database. ${ }^{16}$ This database provides closing prices, trading volumes, open interest, and implied volatilities for all call and put options listed on the US options markets. The sample period starts in January 1996 and ends in December 2011. We exclude options with zero open interest and those without data

\footnotetext{
${ }^{13}$ Results of estimating equations (4) and (5), as well as the estimation of accruals management and unexpected real earnings management, are available from the authors upon request.

${ }^{14}$ We multiply the residuals from equation (5) by -1 (i.e., $-1 \times$ RM_DISX) such that the higher the residuals, the larger the amount of discretionary expenditures cut by the firm to inflate reported earnings. This transformation aligns the interpretation of the sign of RM_DISX with that of RM_PROD, i.e., positive values of both equate to real activities manipulations. Thus, we are able to add them (i.e., RM_PROD + the transformed value of RM_DISX) to obtain the composite score RM. ${ }^{15}$ The estimations of U_RM and AM are available upon request from the authors.

${ }^{16}$ Papers that use the database include Feng et al. (2014) and Goyal and Saretto (2009).
} 
on implied volatility. We also eliminate financial institutions (SIC 6000-6999) and utility firms (SIC 4900-4999) from the sample given their regulated status.

We obtain monthly short interest data from the COMPUSTAT Supplement File for the sample period. Data on share prices, daily stock returns, number of shares outstanding, and trading volume are obtained from the CRSP database. The final sample includes firms with data available on options trading, short selling, and earnings management, and consists of 85,356 firm-quarter observations, equivalent to 3,868 firms. Table 1 shows the sample distribution by year in panel $\mathrm{A}$; the average number of outstanding call contracts and put contracts per firm at each month end, as well as the average moneyness of the contracts in Panel B.

\section{[INSERT TABLE 1 ABOUT HERE]}

Table 2 reports descriptive statistics on the various measures used in the analyses. The average firm in the sample reports $\$ 1,569$ million in sales, $\$ 6,990$ million in assets and return on asset of $-0.1 \%$ (based on figures obtained from the Compustat Quarterly database). The mean market capitalization is $\$ 6,532$ million, and the average capital structure is made up of $50 \%$ debt. The rest of the table presents descriptive statistics on SHINT, VSKEW, VSPREAD, RM, RM_PROD and RM_DISX.

\section{[Insert Table 2 about here]}

We present a correlation matrix of the variables in Panel B of Table 2. The variables SHINT, VSPREAD and VSKEW, which represent short interest, volatility spread and volatility skew, respectively, are positively correlated with each other. SHINT is negatively correlated to the earnings management variables, suggesting that firms with higher earnings management scores are associated with lower levels of SHINT. Conversely, VSPREAD and 
$V S K E W$ are positively correlated with the earnings management variables. $R M_{-} P R O D$, which represents abnormal production cost, is positively and significantly related to VSKEW and VSPREAD, respectively. The respective correlation coefficients are 0.0151 and 0.0210 . Thus, the spread between the put and call options is positively correlated with real earnings management.

\section{Empirical Results}

\subsection{Univariate results}

Table 3 presents firm characteristics by quartiles of short interest (SHINT), volatility spread $(V S P R E A D)$ and volatility skew $(V S K E W)$ in panels A, B and C, respectively. The results show that short sellers tend to target firms with larger revenues, higher debt ratio, probability of informed trading (PIN), market share, return on assets (ROA) and illiquidity (also see Lin and Lu, 2015). Options traders, on the other hand, tend to target firms with lower debt ratio and PIN. Note that VSPREAD and VSKEW are constructed as the differences in the implied volatility of the put and the call (put minus call) options and thus capture the negative sentiment of informed trading. Both short sellers and options traders prefer to trade in firms with low market-to-book ratio and high institutional ownership. The short-selling level is higher among firms followed by more analysts.

\section{[Insert Table 3 about here]}

We break the sample into quartiles based on $R M-$ i.e. the variable measuring real earnings management. We then compare the mean and median scores of SHINT, VSPREAD and $V S K E W$ between the top and bottom quartiles using a $t$-test and the non-parametric Wilcoxon test and present our findings in Table 4. 
The levels of VSKEW and VSPREAD differ significantly between the highest and lowest quartiles of the various real earnings management $(R M)$ measures in Panel A. They are significantly higher in the top quartile (i.e. quartile 4) when compared to the bottom quartile (i.e. quartile 1). The differences in means and medians are highly significant. Thus, firms that manage their earnings the most are the ones with the largest options volatility spread and skew. ${ }^{17}$ We obtain similar findings using alternative measurements of real earnings management; i.e. $R M_{-} P R O D$ representing abnormal production costs in Panel $\mathrm{B}$ and $U_{-} R M$ representing unexpected real earnings management in Panel D. VSKEW and VSPREAD continue to be higher in the quartile representing the highest earnings manipulators (Q4) compared to the quartile representing the lowest manipulators (Q1).

Conversely, SHINT is lower in the top quartiles of the various real earnings management measures and higher in the bottom quartiles (see Panels A, B, C and D of Table 4). This result is not consistent with prior literature (for instance, Desai et al. 2006). This difference can be explained by the fact that our sample includes the universe of COMPUSTAT firms with available options trading and short-selling data, while Desai et al. (2006) examine firms that have restated their financial statements.

The direct association between the high $R M$ quartiles and the higher levels of $V S P R E A D$ and $V S K E W$, respectively, suggests that $R M$ leads to higher uncertainty in stock valuations. The contrasting results between short sellers and options traders suggest that investors in the options market trade in a way that is consistent with the expectations of the uncertain effects of $R M$. In the following section, we test whether these associations persist in multivariate regressions.

\footnotetext{
${ }^{17} \mathrm{We}$ also analyse the findings by quarter, i.e. quarter -4 to -1 with quarter 0 representing the one in which we calculate RM, and our findings stay the same.
} 


\subsection{Multivariate Regressions of Short Interest}

Table 5 presents the results from GMM panel regressions of short interest on real activities manipulations. ${ }^{18}$

\section{[INSERT TABLE 5 ABOUT HERE]}

Consistent with our earlier explanations, we find that the variables representing real

earnings management, in particular, $R M$, are not related to the dependent variable SHINT,

which represents short interest (Model 1). The same is true for the component variables

making up $R M$, i.e. $R M_{-} P R O D, R M \_D I S X$ and $U_{-} R M$ in Models 2,3 and 4, respectively. ${ }^{19}$

\footnotetext{
${ }^{18}$ We rerun all regressions using basic OLS and our findings stay the same. We estimate equation (1) by correcting the standard errors for firm clustering effect following Rogers (1994), which allows for intragroup correlation by relaxing the usual requirement that the observations are independent. Thus, while the observations are independent across firms, they are not necessarily independent within a firm. We also control for quarterly and industry fixed effects.

${ }^{19}$ The uncertainty in valuation brought about by RM can go both ways. For instance, Gunny (2010) argues that engaging in RM is not opportunistic but enables the firm to signal expected superior performance. Conversely, RM may lead to overvalued securities followed by a correction in prices. We test the hypothesis that short-selling would be related to real earnings management under scenarios where there is less ambiguity on its adverse effects. We create subsamples whereby real earnings management is detrimental to the firm value and would provide short sellers with the incentive to short-sell the shares of the firms. We then run equation (1) using OLS in each subsample to test the effect of U_RM (unexpected real earnings management) on SHINT (the level of short interest). Scenario 1: First, we focus on the "abnormally" high and low levels of real earnings management (U_RM). We surmise that "abnormally" high levels of real earnings management would suggest that the intentions to manipulate earnings is less ambiguous. In the subsample of positive U_RM (i.e., the subsample where real earnings management is more detrimental to firm value), there is no association between SHINT and U_RM (as well as in various other subsamples). Scenario 2: Second, we focus on the ratio of book-to-market, which serves as a useful indicator of future stock return, i.e., high (low) values of the ratio are associated with more (less) favourable future stock returns. In various subsamples comprising of firms with the lowest book-to-market ratios, the relationship between SHINT and the independent variable of interest, i.e., U_RM is not statistically significant. Scenario 3: Third, we consider research and development expenditures. To the extent that $R \& D$ is directly related to future stock returns, we hypothesize that minimal $R \& D$ expenditure would be damaging. Thus, we break the sample into two, i.e., firms with above median R\&D/Sales and those with below median R\&D/Sales and hypothesize that the use of RM in the subsample of below-median $\mathrm{R} \& \mathrm{D} / \mathrm{Sales}$ would be unambiguously detrimental and short sellers would have clear options to shortsell. However, the coefficient of U_RM in the regression of SHINT for the subsample of firms with below median $R \& D / S a l e$ is statistically insignificant. Similarly, the coefficient is not significant in the tercile of firms with the lowest $\mathrm{R} \& \mathrm{D} / \mathrm{Sales}$. Conversely, the relationship between each of options spread and skew, and U_RM is positive and highly significant in every subsample mentioned above. As a result, our main findings stay the same, i.e., there exists a statistically significant association between options volatility and real earnings management but not between short-selling and real earnings management.
} 
Note that the legal scrutiny that accompanies short selling can be onerous. For instance, the US Securities and Exchange Commission (SEC) has adopted a series of rules to restrict abusive short-sale practices, and specifies the conditions under which short-sale orders are now permitted. SEC also empowers a broker to close an investor's position without consent under certain scenarios. This will inhibit some short sellers from successfully pursuing their trading strategies. To the extent that these complexities as well as the uncertainties associated with the true effects of RM exist, there would be no association between SHINT and RM. Conversely, the identification and purpose of accruals management are not as intricate as real activities manipulations. Consistent with Desai et al. (2006) and Hirshleifer et al. (2011), we find that there exists a higher level of short interest (SHINT) in the stocks of firms with high scores for accruals management $(A M)$.

Post-Sarbanes Oxley Act (SOX, 2002), though, firms are making greater use of real activities manipulations than accruals manipulations in managing earnings (Cohen, Dey and Lys, 2008; Zang, 2012). Managers are more inclined to use RM post-SOX as it is more difficult to litigate against RM than against AM. Auditors' assessment of internal controls has also become more thorough post-SOX given the legal penalties for failing to do so; and, since AM practices are easier to ascertain, managers would expect auditors to scrutinize such practices more closely. Thus, post-SOX, the inclination to use RM would suggest a stronger association between RM and investors' strategies (for instance, shorting stocks and trading in options) to benefit from RM during that period. To test for the SOX effect, we break the sample into two time periods, i.e. pre- and post-SOX and test whether the effect of real earnings management on short interest changes with the passage of SOX. We present the findings in the last two columns of Table 5. The coefficient representing unexpected real earnings management - i.e. $U_{-} R M$ - remains statistically insignificant in both time periods. 
The findings suggest that there exists no link between short selling and firms' usage of abnormally high levels of real earnings manipulation.

\subsection{Multivariate Regressions of Options Volatility}

The univariate results show that the top quartiles of $R M$ are associated with the highest volatility spread (VSPREAD) and skew (VSKEW). In this section, we test whether these findings hold in multivariate regressions and present our results in Tables 6 and 7. The dependent variable is VSPREAD and VSKEW in Tables 6 and 7, respectively. Model 4 of Table 6 includes both $U_{-} R M$ and $A M$. These two variables are orthogonalized with respect to each other: i.e. in arriving at $U_{-} R M$, we control for $A M$, since as explained by Zang (2012), managers often resort to $A M$ by yearend when $R M$ (which is usually implemented throughout the year) has failed to achieve the desired outcomes (for example, meeting earnings target).

\section{[INSERT TABLES 6 \& 7 ABOUT HERE]}

Irrespective of the model used, $R M$ is always positively and significantly related to the option volatility measures of VSPREAD and VSKEW. The same is true for two other measures of real activities manipulation - i.e. $R M_{-} P R O D$ in Model 2 and $U_{-} R M$ in Model 4. These confirm the univariate findings that options spread and skew are larger amongst firms that engage in real activities manipulation. As we explained earlier, $R M$ introduces noise in the information content of reported earnings. Given that investors differ in their ability to assess earnings-related information, $R M$ is interpreted in different ways by investors. The result is a rise in the option volatility of the underlying securities, which is consistent with finding a positive association between option volatility skew and RM.

The interpretation of the other variables is as follows. RM_DISX represents belowaverage expenditure on discretionary expenses, which is associated with firms manipulating 
earnings. The lower the value of RM_DISX, the higher the likelihood the firm is abnormally reducing discretionary expenditure to manipulate earnings, and the higher the options volatility spread due to a larger information asymmetry, which is a consequence of manipulating discretionary expenditure. The relationship between $R M_{-} D I S X$ and the option volatility spread is, therefore, negative as evidenced by the negative coefficient.

Post-SOX firms are making greater use of real activities manipulations in managing earnings (Cohen, Dey and Lys, 2008), and therefore we would expect investors to be more concerned about the adverse effect of real earnings management on share prices following SOX. Consistent with this hypothesis, we find that the enactment of SOX changed investors' apprehension about firms engaged in manipulating real activities. Breaking the sample into two time periods - i.e. pre- and post-SOX - we find in the last two columns that our real earnings management variable is negatively and significantly related to both VSPREAD and VSKEW prior to SOX but that the relationship changes from negative to positive post-SOX. After the passage of the legislation, there exists a direct relationship between the level of unexpected real earnings management $\left(U_{-} R M\right)$ and both the options spread (VSPREAD) and skewness (VSKEW).

We also document the following. PIN refers to the probability of informed trading and is positively and significantly related to the option volatility spread (VSPREAD). The positive association is consistent with Johnson (2009), who argues that the securitiesinformed traders who trade more actively will exhibit higher bid-ask spreads and more informative order flow. Dennis, Mayhew and Stivers (2006) find significant differences in implied volatilities across firms ranked in size. Consistent with their findings, we find that the coefficient representing firm size - i.e. $L M C$ - is significantly related to VSPREAD and VSKEW. 
VSPREAD refers to the difference in the implied volatilities of put and call options. It is directly related to the put option's implied volatility and is inversely related to the call option's implied volatility. In turn, the bid-ask spread is directly related to the option's volatility (be it put or call options). VSPREAD is either associated with an increase in put volatility (which is associated with an increase in the put bid-ask spread - i.e. $P S$ ) or associated with a decrease in call volatility (which is associated with a decrease in the call bid-ask spread - i.e. $C S$ ). Thus, we would expect VSPREAD to be inversely related to the spreads on call options $(C S)$ and positively related to the spreads on put options (PS). This is indeed the case as the coefficient of $C S$ is negative and that of $P S$ is positive.

\subsection{Three-Stage Least Squared Regressions (3SLS)}

We use a second method to control for the possibility that the levels of short sale, options volatility and real earnings management can be jointly affected by unobserved heterogeneity such as the regulatory environment and corporate governance factors. We estimate a system of equations using 3SLS on the effects of real activities manipulations on short interests and options volatility, respectively, and present our findings in Table 8 . We present two models in Table 8 and both consist of two equations representing option volatility (i.e., VSPREAD in Model 1 and VSKEW in Model 2) and short interest (SHINT), respectively.

\section{[INSERT TABLE 8 ABOUT HERE]}

Similar to the univariate findings and the GMM panel regressions, there exists a positive and significant association between the abnormally high levels of real earnings management ( $U_{-} R M$ used as the proxy) and each of option spread from Model 1 and option skewness from Model 2. The coefficient $U_{-} R M$ is significant beyond the $1 \%$ level in both models. 


\section{Summary and Conclusion}

We examine the association between firms' use of real activities manipulations (RM) and the trades of options traders and short sellers. We document a positive association between RM and two measures of options' implied volatility. The positive association is consistent with the hypothesis that RM creates more uncertainty about the true value of the firm and therefore leads to higher volatility in its share prices. To the extent that RM leads to higher volatility, then both the implied volatilities of call and put options would rise. However, the use of RM is more likely to artificially increase the stock price, which suggests that a downward correction in the stock price is likely. Consequently, unlike long positions in call options, similar positions in put options offer greater protection to investors trying to exploit the effects of RM on share prices. Consistent with this hypothesis, we document an increase in the amount by which the implied volatility of put options exceeds that of corresponding call options. We obtain similar findings using a more stringent measure of option volatility, i.e. the options skew which considers the extent to which the implied volatilities of out-of-the-money put options exceed those of corresponding at-the-money call options. The empirical evidence suggests that options traders expect real earnings management to alter a firm's future stock return distributions. Conversely, and in multivariate tests, we fail to find an association between RM and short selling. We argue that the uncertain effects of RM disincentivise short selling. Besides, the restrictions imposed on short sellers could conceivably inhibit the profitable use of short selling to exploit RM practices. 


\section{References}

Amihud, Y. (2002). Illiquidity and stock returns: cross-section and time-series effects. Journal of financial markets, 5(1), 31-56.

Amin, K. I., \& Lee, C. (1997). Option Trading, Price Discovery, and Earnings News Dissemination. Contemporary Accounting Research, 14(2), 153-192.

Anderson, R. C., Reeb, D. M., Zhang, Y., \& Zhao, W. (2013). The efficacy of regulatory intervention: Evidence from the distribution of informed option trading. Journal of Banking \& Finance, 37(11), 4337-4352.

Aragon, G. O., \& Martin, J. S. (2012). A unique view of hedge fund derivatives usage: Safeguard or speculation?. Journal of Financial Economics, 105(2), 436-456.

Arellano, M., \& Bond, S. (1991). Some tests of specification for panel data: Monte Carlo evidence and an application to employment equations. The Review of Economic Studies, 58(2), 277-297.

Arellano, M., \& Bover, O. (1995). Another look at the instrumental variable estimation of error-components models. Journal of Econometrics, 68(1), 29-51.

Asquith, P., \& Meulbroek, L. K. (1995). An empirical investigation of short interest. Division of Research, Harvard Business School.

Asquith, P., Pathak, P. A., \& Ritter, J. R. (2005). Short interest, institutional ownership, and stock returns. Journal of Financial Economics, 78(2), 243-276.

Atieh, A., \& Hussain, S. (2012). Do UK firms manage earnings to meet dividend thresholds?. Accounting and Business Research, 42(1), 77-94.

Atilgan, Y. (2014). Volatility spreads and earnings announcement returns. Journal of Banking \& Finance, 38, 205-215.

Bhattacharya, N., Desai, H., \& Venkataraman, K. (2013). Does Earnings Quality Affect Information Asymmetry? Evidence from Trading Costs. Contemporary Accounting Research, 30(2), 482-516.

Bhojraj, S., Hribar, P., Picconi, M., \& McInnis, J. (2009). Making sense of cents: An examination of firms that marginally miss or beat analyst forecasts. The Journal of Finance, 64(5), 2361-2388.

Blundell, R., \& Bond, S. (2000). GMM estimation with persistent panel data: an application to production functions. Econometric reviews, 19(3), 321-340.

Bollen, N. P., \& Whaley, R. E. (2004). Does net buying pressure affect the shape of implied volatility functions?. The Journal of Finance, 59(2), 711-753.

Bond, S. R. (2002). Dynamic panel data models: a guide to micro data methods and practice. Portuguese economic journal, 1(2), 141-162.

Brown, S., \& Hillegeist, S. A. (2007). How disclosure quality affects the level of information asymmetry. Review of Accounting Studies, 12(2-3), 443-477.

Callen, J. L., \& Segal, D. (2004). Do Accruals Drive Firm - Level Stock Returns? A Variance Decomposition Analysis. Journal of accounting Research, 42(3), 527-560.

Cao, C., Chen, Z., \& Griffin, J. M. (2005). Informational Content of Option Volume Prior to Takeovers. The Journal of Business, 78(3), 1073-1109.

Cohen, D. A., \& Zarowin, P. (2010). Accrual-based and real earnings management activities around seasoned equity offerings. Journal of Accounting and Economics, 50(1), 2-19.

Cohen, D. A., Dey, A., \& Lys, T. Z. (2008). Real and accrual-based earnings management in the pre-and post-Sarbanes-Oxley periods. The accounting review, 83(3), 757-787.

Cremers, M. \& Weinbaum, D. (2010). Deviations from Put-Call Parity and Stock Return Predictability. Journal of Financial and Quantitative Analysis, 45(2), 335-367. 
Dechow, P. M., Sloan, R. G., \& Sweeney, A. P. (1995). Detecting earnings management. Accounting review, 193-225.

Dennis, P., Mayhew, S. and C. Stivers, 2006. Stock Returns, Implied Volatility Innovation, and the Asymmetric Volatility Phenomenon, Journal of Financial and Quantitative Analysis 41(2), 381-406.

Desai, H., Krishnamurthy, S., \& Venkataraman, K. (2006). Do short sellers target firms with poor earnings quality? Evidence from earnings restatements. Review of Accounting Studies, 11(1), 71-90.

Donders, M., Kouwenberg, R., \& Vorst, T. (2000). Options and earnings announcements: an empirical study of volatility, trading volume, open interest and liquidity. European Financial Management, 6(2), 149-171.

Easley, D., Hvidkjaer, S., \& O'Hara, M. (2002). Is information risk a determinant of asset returns?. The Journal of Finance, 57(5), 2185-2221.

Easley, D., O'Hara, M. and Srinivas, P.S. (1998), Option Volume and Stock Prices: Evidence on Where Informed Traders Trade. The Journal of Finance, 53: 431-465.

Fang, V. W., Huang, A. H., \& Karpoff, J. M. (2016). Short selling and earnings management: A controlled experiment. The Journal of Finance, 71: 1251-1294.

Feng, S. P., Hung, M. W., \& Wang, Y. H. (2014). Option pricing with stochastic liquidity risk: Theory and evidence. Journal of Financial Markets, 18, 77-95.

Garleanu, N., Pedersen, L. H., \& Poteshman, A. M. (2009). Demand-based option pricing. Review of Financial Studies, 22, 4259-4299.

Goyal, A., \& Saretto, A. (2009). Cross-section of option returns and volatility. Journal of Financial Economics, 94(2), 310-326.

Grundy, B. D., Lim, B., \& Verwijmeren, P. (2012). Do option markets undo restrictions on short sales? Evidence from the 2008 short-sale ban. Journal of Financial Economics, 106(2), 331-348.

Gunny, K. (2010) The Relation Between Earnings Management Using Real Activities Manipulation and Future Performance: Evidence from Meeting Earnings Benchmarks. Contemporary Accounting Research, 27(3), 855-888.

Hirshleifer, D., Teoh, S. H., \& Yu, J. J. (2011). Short arbitrage, return asymmetry, and the accrual anomaly. Review of Financial Studies, 24(7), 2429-2461.

Jennings, R., \& Starks, L. (1986). Earnings announcements, stock price adjustment, and the existence of option markets. The journal of Finance, 41(1), 107-125.

Jin, W., Livnat, J., \& Zhang, Y. (2012). Option Prices Leading Equity Prices: Do Option Traders Have an Information Advantage?. Journal of Accounting Research, 50(2), 401432.

Johnson, T. L. (2009). Mean and Volatility Information in Options Markets. Working Paper, Stanford University.

Jones, J. J. (1991). Earnings management during import relief investigations. Journal of Accounting Research, 29(2), 193-228.

Kang, S. H., \& Sivaramakrishnan, K. (1995). Issues in testing earnings management and an instrumental variable approach. Journal of Accounting Research, 33(2), 353-367.

Karpoff, J. M., \& Lou, X. (2010). Short sellers and financial misconduct. The Journal of Finance, 65(5), 1879-1913.

Kim, B., Lisic, L. L., \& Pevzner, M. (2011). Debt covenant slacks and real earnings management. George Mason University.

Kim, J. B., \& Sohn, B. C. (2013). Real earnings management and cost of capital. Journal of Accounting and Public Policy, 32(6), 518-543. 
Li, Xi, Real Earnings Management and Subsequent Stock Returns (February 4, 2010). Available at SSRN: https://ssrn.com/abstract $=1679832$ or http://dx.doi.org/10.2139/ssrn.1679832

Lin, T. C., \& Lu, X. (2015). Why do options prices predict stock returns? Evidence from analyst tipping. Journal of Banking \& Finance, 52, 17-28.

Liu, A. Z., Subramanyam, K. R., Zhang, J., \& Shi, C. (2017). Do Firms Manage Earnings to Influence Credit Ratings? Evidence from Negative Credit Watch Resolutions. The Accounting Review.

Massa, M., Zhang, B., \& Zhang, H. (2015). The Invisible Hand of Short Selling: Does Short Selling Discipline Earnings Management?. Review of Financial Studies, 28(6), 17011736.

Ofek, E., Richardson, M., \& Whitelaw, R. F. (2004). Limited arbitrage and short sales restrictions: Evidence from the options markets. Journal of Financial Economics, 74(2), 305-342.

Rangan, S. (1998). Earnings management and the performance of seasoned equity offerings. Journal of Financial Economics, 50(1), 101-122.

Richardson, S. (2003). Earnings quality and short sellers. Accounting Horizons, 17, 49.

Rogers, W. (1994). Regression standard errors in clustered samples. Stata technical bulletin, $3(13)$.

Roychowdhury, S. (2006). Earnings management through real activities manipulation. Journal of accounting and economics, 42(3), 335-370.

Sadka, G. (2007). Understanding stock price volatility: The role of earnings. Journal of Accounting Research, 45(1), 199-228.

Teoh, S. H., Welch, I., \& Wong, T. J. (1998). Earnings management and the underperformance of seasoned equity offerings. Journal of Financial economics, 50(1), 63-99.

Venter, J. H., \& De Jongh, D. C. J. (2006). Extending the EKOP model to estimate the probability of informed trading. Studies in Economics and Econometrics, 30.

Vuolteenaho, T. (2002). What Drives Firm - Level Stock Returns?. The Journal of Finance, 57(1), 233-264.

Wintoki, M.B., J.S. Linck, and J.M. Netter, 2012. Endogeneity and the dynamics of internal corporate governance, Journal of Financial Economics 105, 581-606.

Zang, A. Y. (2012). Evidence on the trade-off between real activities manipulation and accrual-based earnings management. The Accounting Review, 87(2), 675-703. 


\begin{tabular}{lll}
\hline Table 1: Sample Distribution & & \\
\hline Panel A: Sample Distribution by Year & & \\
Year & Number of Observations & \% in the sample \\
\hline 1996 & 2,682 & 3.14 \\
1997 & 3,158 & 3.7 \\
1998 & 3,446 & 4.04 \\
1999 & 3,431 & 4.02 \\
2000 & 2,854 & 3.34 \\
2001 & 2,662 & 3.12 \\
2002 & 2,919 & 3.42 \\
2003 & 4,427 & 5.19 \\
2004 & 6,368 & 7.46 \\
2005 & 6,836 & 8.01 \\
2006 & 7,302 & 8.55 \\
2007 & 7,774 & 9.11 \\
2008 & 7,791 & 9.13 \\
2009 & 7,599 & 8.9 \\
2010 & 7,946 & 9.31 \\
2011 & 8,161 & 9.56 \\
Total & 85,356 & 100 \\
\hline
\end{tabular}

Panel B - Distribution of Options per Firm at Month End

\begin{tabular}{llll} 
Variables & Mean & Median & Standard deviation \\
\hline Number of call option contracts & 38.82 & 27.00 & 33.88 \\
Number of put option contracts & 38.80 & 27.00 & 33.89 \\
Number of ATM call option contracts & 5.00 & 5.00 & 1.24 \\
Number of ITM call option contracts & 19.61 & 14.00 & 18.75 \\
Number of OTM call option contracts & 19.97 & 14.00 & 18.68 \\
Number of ATM put option contracts & 4.98 & 5.00 & 1.26 \\
Number of ITM put option contracts & 19.97 & 14.00 & 18.68 \\
Number of OTM put option contracts & 19.58 & 14.00 & 18.76 \\
\hline
\end{tabular}

This table provides the sample frequency by year. The sample includes 3,868 firms from the COMPUSTAT database. We exclude financial and utility firms, as they are heavily regulated firms. Selected firms should have option data on the Ivy DB OptionMetrics database and share prices' data on the CRSP database. ATM, ITM and OTM represent at the money, in the money and out of the money options, respectively. 


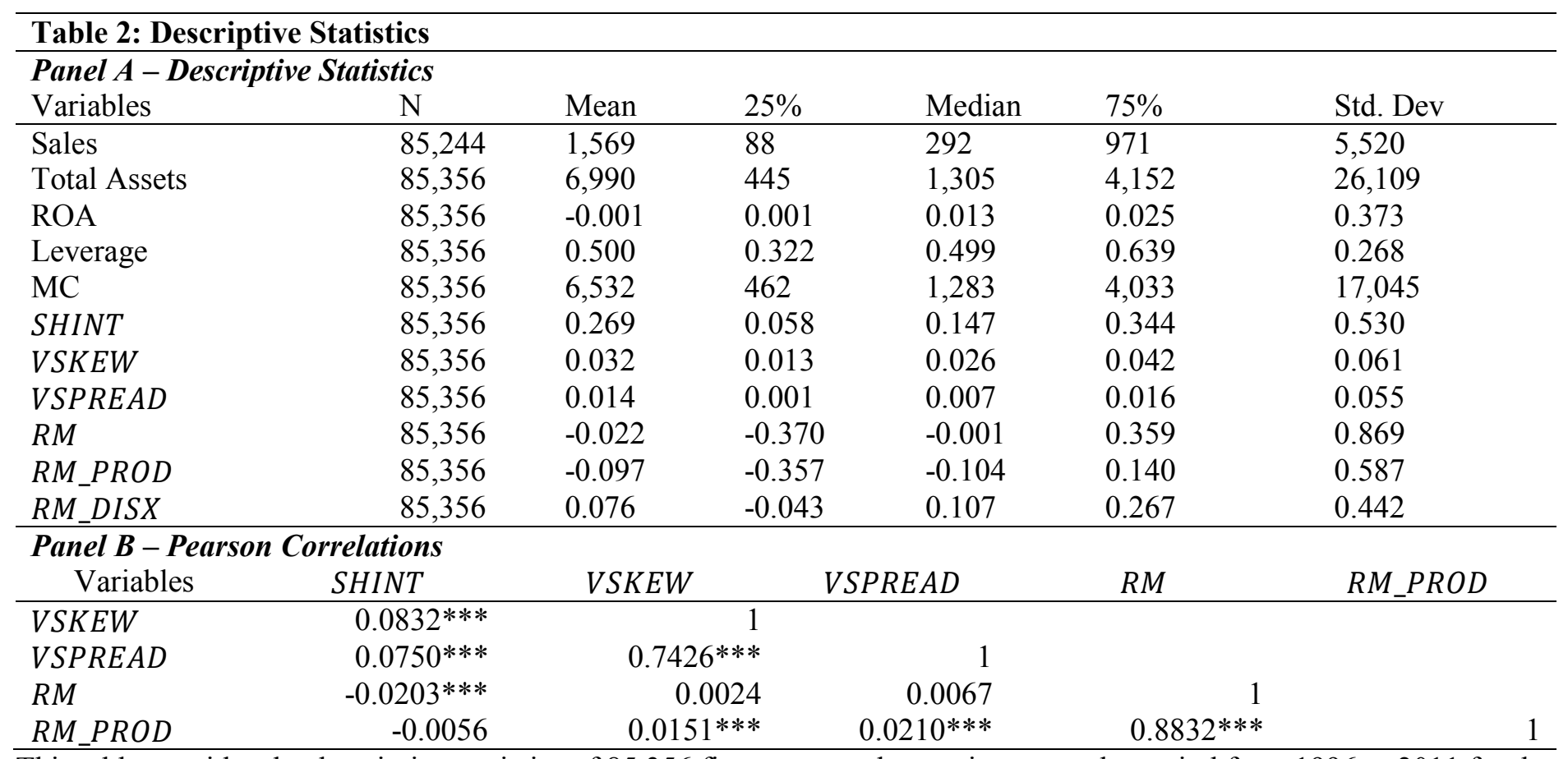

This table provides the descriptive statistics of 85,356 firm-quarter observations over the period from 1996 to 2011 for the pooled sample. Sales is the net sales; Total Assets is the book value of total assets; ROA is ratio of income before extraordinary item to total assets; Leverage is the ratio of total debt to total assets; MC is the market value of equity; SHINT is the short interest calculated as the short position in a given month scaled by the number of shares outstanding as reported in the CRSP database; VSKEW is the volatility skew calculated as the implied volatility of the OTM put option minus the implied volatility of the ATM call option; VSPREAD is the volatility spread that measures the difference between the implied volatility of a put option and its corresponding call option matched on strike price and maturity date. $R M, R M_{-} P R O D$ and $R M_{-} D I S X$ are the total real activities manipulation, abnormal production cost and abnormal discretionary expenditure, respectively. ${ }^{*}, * *$, and $* * *$ indicate significance at the $10 \%, 5 \%$, and $1 \%$ levels, respectively. 
Table 3: Firm Characteristics by Quartiles of Short Interest, Volatility Spread and Volatility Skew

Panel A - Firm Characteristics by Quartiles of Short Interest (SHINT)

\begin{tabular}{|c|c|c|c|c|c|c|c|}
\hline Firm characteristics & Q1 & Q2 & Q3 & Q4 & Q4 - Q1 & t-stat & Wilcoxon \\
\hline Sales & 623.710 & 951.590 & $1,351.050$ & $3,349.520$ & $2,725.810$ & $42.57 * * *$ & $63.95 * * *$ \\
\hline $\mathrm{MC}$ & $17,271.450$ & $4,193.410$ & $6,316.580$ & $16,862.690$ & -408.760 & -0.12 & -0.63 \\
\hline MB & 2.399 & 2.137 & 2.065 & 1.977 & -0.422 & $-22.07 * * *$ & $-14.67 * * *$ \\
\hline Leverage & 0.472 & 0.465 & 0.471 & 0.496 & 0.024 & $11.67 * * *$ & $12.33 * * *$ \\
\hline PIN & 0.126 & 0.125 & 0.124 & 0.130 & 0.004 & $5.85 * * *$ & $2.39 * *$ \\
\hline Market Share (\%) & $5.369 \%$ & $6.536 \%$ & $7.414 \%$ & $9.804 \%$ & 0.044 & $32.67 * * *$ & $44.83 * * *$ \\
\hline ROA (\%) & $-0.759 \%$ & $-0.237 \%$ & $0.248 \%$ & $0.219 \%$ & 0.010 & $2.94 * * *$ & $35.56 * * *$ \\
\hline Illiquidity & $0.780 \%$ & $0.835 \%$ & $1.078 \%$ & $2.155 \%$ & $1.376 \%$ & $15.11 * * *$ & $14.78 * * *$ \\
\hline \multicolumn{8}{|l|}{ Institutional } \\
\hline Ownership & $43.257 \%$ & $53.651 \%$ & $55.548 \%$ & $56.206 \%$ & $12.949 \%$ & $40.64 * * *$ & $42.91 * * *$ \\
\hline Number of Analysts & 8.70 & 8.74 & 9.23 & 9.17 & $46.936 \%$ & $6.24 * * *$ & $4.86 * * *$ \\
\hline \multicolumn{8}{|c|}{ Panel B - Firm Characteristics by Quartiles of Volatility Spread (VSPREAD) } \\
\hline Firm characteristics & Q1 & Q2 & Q3 & Q4 & Q4 - Q1 & t-stat & Wilcoxon \\
\hline Sales & $1,275.080$ & $1,711.790$ & $2,188.370$ & $1,097.170$ & -177.910 & $-1.82 *$ & -1.07 \\
\hline $\mathrm{MC}$ & $6,287.220$ & $14,223.550$ & $17,052.890$ & $6,876.590$ & 589.370 & 0.49 & 0.69 \\
\hline MB & 2.248 & 2.184 & 2.169 & 1.973 & -0.275 & $-14.18 * * *$ & $-7.19 * * *$ \\
\hline Leverage & 0.474 & 0.486 & 0.484 & 0.460 & -0.014 & $-6.42 * * *$ & $-6.38 * * *$ \\
\hline PIN & 0.143 & 0.116 & 0.110 & 0.137 & -0.006 & $-3.19 * * *$ & $-11.58 * * *$ \\
\hline Market Share (\%) & $6.144 \%$ & $8.316 \%$ & $8.854 \%$ & $5.802 \%$ & -0.003 & -0.81 & 0.17 \\
\hline ROA $(\%)$ & $-0.932 \%$ & $0.528 \%$ & $0.682 \%$ & $-0.809 \%$ & 0.001 & 0.35 & 1.06 \\
\hline Illiquidity & $1.954 \%$ & $0.680 \%$ & $0.566 \%$ & $1.650 \%$ & $-0.304 \%$ & -0.43 & -1.25 \\
\hline \multicolumn{6}{|l|}{ Institutional } & \multirow{2}{*}{$22.77 * * *$} & \multirow{3}{*}{$23.01 * * *$} \\
\hline Ownership & $43.818 \%$ & $55.730 \%$ & $58.128 \%$ & $50.971 \%$ & $7.153 \%$ & & \\
\hline Number of Analysts & 6.72 & 9.79 & 11.24 & 8.09 & 1.37 & 1.17 & \\
\hline
\end{tabular}

\begin{tabular}{llllllll}
\hline \multicolumn{2}{l}{ Panel C - Firm Characteristics by } & \multicolumn{9}{l}{ Quartiles of Volatility Skew } & (VSKEW) & & & \\
Firm characteristics & $\mathrm{Q} 1$ & $\mathrm{Q} 2$ & $\mathrm{Q}$ & $\mathrm{Q} 4$ & $\mathrm{Q} 4-\mathrm{Q} 1$ & $\mathrm{t}$-stat & Wilcoxon \\
\hline Sales & $1,415.190$ & $1,789.630$ & $2,126.470$ & 941.160 & -474.030 & $-1.99^{* *}$ & $-2.13^{* * *}$ \\
MC & $5,794.940$ & $13,473.210$ & $15,756.430$ & $9,471.240$ & $3,676.300$ & $2.11^{* *}$ & $2.13^{* *}$ \\
MB & 2.314 & 2.216 & 2.099 & 1.946 & -0.368 & $-18.9^{* * *}$ & $-11.07^{* * *}$ \\
Leverage & 0.472 & 0.481 & 0.490 & 0.462 & -0.010 & $-4.69^{* * *}$ & $-4.11^{* * *}$ \\
PIN & 0.138 & 0.115 & 0.114 & 0.118 & -0.020 & $-3.21^{* * *}$ & $-2.44^{* *}$ \\
Market Share (\%) & $5.863 \%$ & $8.341 \%$ & $8.717 \%$ & $6.196 \%$ & 0.003 & 0.69 & 0.75 \\
ROA (\%) & $-1.101 \%$ & $0.545 \%$ & $0.713 \%$ & $-0.689 \%$ & 0.004 & $1.7 *$ & 1.02 \\
Illiquidity & $1.672 \%$ & $0.722 \%$ & $0.729 \%$ & $1.726 \%$ & $0.054 \%$ & 0.74 & 0.9 \\
Institutional & & & & & & & \\
Ownership & $47.102 \%$ & $55.593 \%$ & $56.541 \%$ & $49.415 \%$ & $2.313 \%$ & $7.4^{* * *}$ & $7.16^{* * *}$ \\
Number of Analysts & 7.33 & 10.03 & 10.54 & 7.93 & 0.60 & 1.27 & 1.28 \\
\hline
\end{tabular}

The table presents firm characteristics by quartiles of short interest (SHINT), volatility spread (VSPREAD) and volatility skew (VSKEW) in panels A, B and C, respectively. Sales is the net sales; MC is the market value of equity; MB is the ratio of the market price per share-to-the book value of the share; Leverage is the ratio of total debt to total assets; PIN is probability of informed trading; Market Share represents the ratio of the firm's sales-to-total sales of all firms in the same industry. The data are obtained from COMPUSTAT. ROA is ratio of income before extraordinary item to total assets. Illiquidity ratio is the average ratio of the daily absolute return to the dollar trading volume. It is calculated over a oneyear period ending a month prior to quarter $t$. The data are obtained from Compustat. Institutional Ownership represents the percentage of the shares outstanding held by institutional owners as reported in the Thomson Financial database. The number of analysts is obtained from the IBES database. *,**, and *** indicate significance at the $10 \%, 5 \%$, and $1 \%$ levels, respectively. 
Table 4: Short Interest, Volatility Skew, and Volatility Spread by Earnings Management Quartiles

Panel A - Ranking by average level of RM in the preceding quarter

\begin{tabular}{|c|c|c|c|c|c|c|c|c|c|c|c|c|}
\hline \multirow[b]{2}{*}{ Variables } & \multicolumn{2}{|c|}{ Q4, High RM } & \multicolumn{2}{|l|}{ Q3 } & \multicolumn{2}{|l|}{ Q2 } & \multicolumn{2}{|c|}{ Q1, Low RM } & \multicolumn{4}{|c|}{ Q4 minus Q1 } \\
\hline & Mean & Median & Mean & Median & Mean & Median & Mean & Median & Diff Mean & Diff Median & t-test & Wilcoxon \\
\hline SHINT & 0.272 & 0.148 & 0.258 & 0.144 & 0.255 & 0.142 & 0.292 & 0.159 & -0.020 & -0.010 & $-4.9 * * *$ & $-4.1 * * *$ \\
\hline VSKEW & 0.035 & 0.027 & 0.031 & 0.026 & 0.030 & 0.025 & 0.033 & 0.026 & 0.002 & 0.001 & $4.1 * * *$ & $2.1 * *$ \\
\hline VSPREAD & 0.017 & 0.008 & 0.013 & 0.007 & 0.012 & 0.007 & 0.014 & 0.007 & 0.002 & 0.000 & $5.1 * * *$ & $4.7 * * *$ \\
\hline
\end{tabular}

\section{Panel B - Ranking by average level of RM_PROD in the preceding quarter}

$\begin{array}{lllll}\text { Q4, High RM } & \text { Q3 } & \text { Q2 } & \text { Q1, Low RM } & \text { Q4 minus Q1 }\end{array}$

\begin{tabular}{cllllllllllll} 
Variables & Mean & Median & Mean & Median & Mean & Median & Mean & Median & Diff Mean & Diff Median & $t$-test & Wilcoxon \\
\hline SHINT & 0.281 & 0.156 & 0.258 & 0.143 & 0.255 & 0.142 & 0.283 & 0.151 & -0.003 & 0.005 & -0.4 & $2.5^{* *}$ \\
VSKEW & 0.035 & 0.027 & 0.032 & 0.026 & 0.030 & 0.025 & 0.032 & 0.026 & 0.003 & 0.001 & $5^{* * *}$ & $4.2^{* * *}$ \\
VSPREAD & 0.017 & 0.008 & 0.014 & 0.007 & 0.012 & 0.007 & 0.014 & 0.007 & 0.003 & 0.001 & $5.4^{* * *}$ & $5.1^{* * *}$ \\
\hline
\end{tabular}

Panel C-Ranking by average level of RM_DISX in the preceding quarter

\begin{tabular}{|c|c|c|c|c|c|c|c|c|c|c|c|c|}
\hline \multirow[b]{2}{*}{ Variables } & \multicolumn{2}{|c|}{ Q4, High RM } & \multicolumn{2}{|l|}{ Q3 } & \multicolumn{2}{|l|}{ Q2 } & \multicolumn{2}{|c|}{ Q1, Low RM } & \multicolumn{4}{|c|}{ Q4 minus Q1 } \\
\hline & Mean & Median & Mean & Median & Mean & Median & Mean & Median & Diff Mean & Diff Median & t-test & Wilcoxon \\
\hline SHINT & 0.262 & 0.143 & 0.262 & 0.143 & 0.265 & 0.143 & 0.297 & 0.171 & -0.036 & -0.027 & $-9.2 * * *$ & $-11.2 * * *$ \\
\hline$V S K E W$ & 0.034 & 0.026 & 0.034 & 0.026 & 0.030 & 0.026 & 0.034 & 0.027 & 0.000 & 0.000 & 0.4 & 0.2 \\
\hline VSPREAD & 0.016 & 0.007 & 0.016 & 0.007 & 0.012 & 0.007 & 0.016 & 0.007 & 0.000 & 0.000 & 0.1 & 1.2 \\
\hline
\end{tabular}

\section{Panel D - Ranking by average level of $U$ RM in the preceding quarter}

\begin{tabular}{|c|c|c|c|c|c|c|c|c|c|c|c|c|}
\hline \multirow[b]{2}{*}{ Variables } & \multicolumn{2}{|c|}{ Q4, High RM } & \multirow{2}{*}{$\begin{array}{l}\text { Q3 } \\
\text { Mean }\end{array}$} & \multirow[b]{2}{*}{ Median } & \multirow{2}{*}{$\begin{array}{l}\text { Q2 } \\
\text { Mean }\end{array}$} & \multirow[b]{2}{*}{ Median } & \multicolumn{2}{|c|}{ Q1, Low RM } & \multicolumn{3}{|c|}{ Q4 minus Q1 } & \multirow[b]{2}{*}{ Wilcoxon } \\
\hline & Mean & Median & & & & & Mean & Median & Diff Mean & Diff Median & t-test & \\
\hline SHINT & 0.273 & 0.148 & 0.260 & 0.144 & 0.255 & 0.143 & 0.290 & 0.156 & -0.017 & -0.008 & $-2.6 * * *$ & $-3.7 * * *$ \\
\hline VSKEW & 0.035 & 0.027 & 0.030 & 0.025 & 0.031 & 0.025 & 0.034 & 0.026 & 0.001 & 0.000 & $2.1 * *$ & 1.1 \\
\hline
\end{tabular}

The table shows the mean and median values of short interest (SHINT), volatility spread (VSPREAD), and volatility skew (VSKEW) by quartiles of real activities manipulation (i.e. RM, RM_PROD, RM_DISX and U_RM). RM represents real earnings management, RM_PROD represents abnormal production costs,

RM_DISX represents abnormal discretionary expenditure, and U_RM represents unexpected real earnings management. SHINT is the short interest calculated as the short position in each month scaled by the number of shares outstanding; VSKEW is the volatility skew calculated as the implied volatility of the out-of-themoney put option minus the implied volatility of a corresponding at-the-money call option; VSPREAD is the volatility spread that measures the difference between the implied volatility of a put option and its corresponding call option matched on strike price and maturity date. ***,** and * indicate significance at the $1 \%, 5 \%$ and $10 \%$ levels, respectively. 
Table 5: GMM Panel Regressions of Short Interest on Real Activities Manipulation

\begin{tabular}{|c|c|c|c|c|c|c|}
\hline \multirow[b]{2}{*}{ Independent Variables } & \multicolumn{4}{|c|}{ Full sample } & \multirow[b]{2}{*}{ Pre-SOX } & \multirow[b]{2}{*}{ Post-SOX } \\
\hline & Model 1 & Model 2 & Model 3 & Model 4 & & \\
\hline \multirow[t]{2}{*}{$\operatorname{SHINT}_{t-1}$} & $0.102 *$ & $0.103 * *$ & $0.103^{*}$ & $0.102 *$ & $0.063 * * *$ & $0.768^{* * *}$ \\
\hline & $(0.057)$ & $(0.052)$ & $(0.060)$ & $(0.059)$ & $(0.006)$ & $(0.041)$ \\
\hline \multirow[t]{2}{*}{$R M$} & 0.003 & & & & & \\
\hline & $(0.007)$ & & & & & \\
\hline \multirow[t]{2}{*}{$R M \_P R O D$} & & -0.012 & & & & \\
\hline & & $(0.010)$ & & & & \\
\hline \multirow[t]{2}{*}{$R M \_D I S X$} & & & 0.032 & & & \\
\hline & & & $(0.022)$ & & & \\
\hline \multirow[t]{2}{*}{$U_{-} R M$} & & & & -0.001 & 0.065 & 0.003 \\
\hline & & & & $(0.008)$ & $(0.060)$ & $(0.005)$ \\
\hline \multirow[t]{2}{*}{$A M$} & & & & $0.004 * *$ & $0.027 * *$ & $0.009 * *$ \\
\hline & & & & $(0.002)$ & $(0.013)$ & $(0.004)$ \\
\hline \multirow[t]{2}{*}{ VSPREAD } & $0.787 * * *$ & $0.809 * * *$ & $0.809 * * *$ & $0.789 * * *$ & $0.870 * * *$ & $0.659 * * *$ \\
\hline & $(0.158)$ & $(0.158)$ & $(0.164)$ & $(0.159)$ & $(0.093)$ & $(0.096)$ \\
\hline \multirow[t]{2}{*}{$L M C$} & $-0.013 * *$ & $-0.012 * *$ & $-0.012 * *$ & $-0.013 * *$ & -0.008 & $-0.009 * *$ \\
\hline & $(0.005)$ & $(0.005)$ & $(0.005)$ & $(0.005)$ & $(0.009)$ & $(0.004)$ \\
\hline \multirow[t]{2}{*}{$B M$} & $-0.016 * *$ & $-0.015^{*}$ & $-0.016 * *$ & $-0.016^{* *}$ & $-0.054^{*}$ & $-0.012 * * *$ \\
\hline & $(0.008)$ & $(0.008)$ & $(0.008)$ & $(0.008)$ & $(0.030)$ & $(0.003)$ \\
\hline \multirow[t]{2}{*}{$R$} & $-0.107 * * *$ & $-0.109 * * *$ & $-0.107 * * *$ & $-0.107 * * *$ & $-0.123 * *$ & $-0.011 * * *$ \\
\hline & $(0.026)$ & $(0.029)$ & $(0.025)$ & $(0.026)$ & $(0.056)$ & $(0.004)$ \\
\hline \multirow[t]{2}{*}{$V R$} & $1.109 * * *$ & $1.028 * * *$ & $1.047 * * *$ & $1.118 * * *$ & $3.769 * * *$ & $0.175^{* * *}$ \\
\hline & $(0.257)$ & $(0.235)$ & $(0.234)$ & $(0.265)$ & $(0.598)$ & $(0.034)$ \\
\hline \multirow[t]{2}{*}{ Leverage } & $0.162 * * *$ & $0.166^{* * *}$ & $0.165 * * *$ & $0.162 * * *$ & $0.125 * * *$ & $0.058 * * *$ \\
\hline & $(0.025)$ & $(0.025)$ & $(0.025)$ & $(0.025)$ & $(0.048)$ & $(0.011)$ \\
\hline \multirow[t]{2}{*}{ Illiquidity } & $-0.264 * * *$ & $-0.206^{*}$ & $-0.205^{* * *}$ & $-0.264 * * *$ & $-0.168 * *$ & $-0.079 * *$ \\
\hline & $(0.095)$ & $(0.111)$ & $(0.061)$ & $(0.096)$ & $(0.076)$ & $(0.031)$ \\
\hline \multirow[t]{2}{*}{ Institutional Ownership } & $0.228 * * *$ & $0.236 * * *$ & $0.237 * * *$ & $0.228 * * *$ & $0.294 * * *$ & 0.001 \\
\hline & $(0.032)$ & $(0.027)$ & $(0.036)$ & $(0.035)$ & $(0.056)$ & $(0.018)$ \\
\hline \multirow[t]{2}{*}{ Number of Analysts } & 0.001 & 0.001 & 0.001 & 0.001 & -0.012 & 0.001 \\
\hline & $(0.003)$ & $(0.003)$ & $(0.003)$ & $(0.003)$ & $(0.008)$ & $(0.001)$ \\
\hline Wald Test & $3359 * * *$ & $14697 * * *$ & $3245 * * *$ & $5250 * * *$ & $5581 * * *$ & $4629 * * *$ \\
\hline AR(1) p-value & 0.367 & 0.354 & 0.371 & 0.370 & 0.179 & 0.201 \\
\hline Hansen test $p$-value & 1 & 1 & 1 & 1 & 0.981 & 1 \\
\hline Observations & 78,571 & 78,571 & 78,571 & 78,547 & 16,360 & 62,187 \\
\hline Number of panels & 3,741 & 3,741 & 3,741 & 3,741 & 1,230 & 3,308 \\
\hline
\end{tabular}

This table presents the results of GMM panel regressions of short interest on real activities manipulations, while controlling for firm and time fixed effects. $S H I N T_{i, t}$ is the average monthly short interest of firm $i$ in quarter $t . R M$ represents real earnings management, $R M_{-} P R O D$ represents abnormal production costs, $R M_{-} D I S X$ represents abnormal discretionary expenditure, and $U_{-} R M$ represents unexpected real earnings management. $A M$ represents accruals management. VSPREAD is the volatility spread that measures the difference between the implied volatility of a put option and its corresponding call option matched on strike price and maturity date. $L M C_{i, t}$ represents the natural logarithm of market capitalization of firm $i$ in quarter $t . B M_{i, t}$ is the book-to-market ratio calculated as the common value of equity divided by market capitalization. $R_{i, t}$ is the monthly return over the window $(-12,-2)$ about quarter $t$. $V R_{i, t}$ is the standard deviation of the market model residuals using daily returns over a one-year window ending one month prior to quarter $t$. Leverage $e_{i, t}$ is the ratio of total liabilities to total assets. Illiquidity Le $_{i, t}$ is the daily ratio of absolute stock $i$ return to its dollar volume, averaged over a year ending one month prior to quarter $t$. Institutional ownership represents the percentage of the shares outstanding held by institutional owners as reported in the Thomson Financial database. The number of analysts is obtained from the IBES database. Pre- and post-SOX represent the time periods before and after the passage of the 2002 U.S. Sarbanes-Oxley Act, respectively. $T$-values are presented in parentheses. $*, * *$ and $* * *$ represent significance at the $10 \%, 5 \%$ and $1 \%$ levels, respectively. 
Table 6: GMM Panel Regressions of Volatility Spread on Real Activities Manipulation

\begin{tabular}{|c|c|c|c|c|c|c|}
\hline \multirow{2}{*}{$\begin{array}{l}\text { Independent } \\
\text { Variables }\end{array}$} & \multicolumn{4}{|c|}{ Full sample } & \multirow[b]{2}{*}{ Pre-SOX } & \multirow[b]{2}{*}{ Post-SOX } \\
\hline & Model 1 & Model 2 & Model 3 & Model 4 & & \\
\hline \multirow{2}{*}{$V_{S P R E A D_{t-1}}$} & $0.488 * * *$ & $0.487 * * *$ & $0.489 * * *$ & $0.488 * * *$ & $0.791 * * *$ & $0.373 * * *$ \\
\hline & $(0.000)$ & $(0.000)$ & $(0.000)$ & $(0.000)$ & $(0.011)$ & $(0.000)$ \\
\hline \multirow[t]{2}{*}{$R M$} & $0.005 * * *$ & & & & & \\
\hline & $(0.000)$ & & & & & \\
\hline$R M \_P R O D$ & & $\begin{array}{l}0.009 * * * \\
(0.000)\end{array}$ & & & & \\
\hline$R M \_D I S X$ & & & $\begin{array}{l}-0.004 * * * \\
(0.000)\end{array}$ & & & \\
\hline \multirow[t]{2}{*}{$U_{-} R M$} & & & & $0.007 * * *$ & $-0.004 * * *$ & $0.003 * * *$ \\
\hline & & & & $(0.000)$ & $(0.001)$ & $(0.000)$ \\
\hline \multirow[t]{2}{*}{$A M$} & & & & $0.003 * * *$ & $0.002 * *$ & -0.001 \\
\hline & & & & $(0.001)$ & $(0.000)$ & $(0.013)$ \\
\hline \multirow[t]{2}{*}{ SHINT } & 0.001 & 0.001 & 0.000 & 0.001 & $0.007 * * *$ & 0.001 \\
\hline & $(0.004)$ & $(0.004)$ & $(0.002)$ & $(0.004)$ & $(0.002)$ & $(0.001)$ \\
\hline \multirow[t]{2}{*}{ PIN } & $0.049 * *$ & $0.051 * *$ & $0.056^{* *}$ & $0.053 * *$ & 0.063 & $0.053 * *$ \\
\hline & $(0.025)$ & $(0.026)$ & $(0.027)$ & $(0.026)$ & $(0.041)$ & $(0.026)$ \\
\hline \multirow[t]{2}{*}{ Illiquidity } & 0.025 & 0.028 & 0.017 & 0.024 & 0.034 & 0.030 \\
\hline & $(0.022)$ & $(0.023)$ & $(0.021)$ & $(0.022)$ & $(0.039)$ & $(0.022)$ \\
\hline \multirow[t]{2}{*}{$L M C$} & $-0.002 *$ & -0.001 & $-0.002 *$ & $-0.002 * *$ & 0.001 & -0.001 \\
\hline & $(0.001)$ & $(0.001)$ & $(0.001)$ & $(0.001)$ & $(0.001)$ & $(0.001)$ \\
\hline \multirow[t]{2}{*}{ CS } & -0.005 & -0.005 & -0.008 & -0.004 & 0.009 & -0.005 \\
\hline & $(0.007)$ & $(0.007)$ & $(0.007)$ & $(0.007)$ & $(0.043)$ & $(0.007)$ \\
\hline \multirow[t]{2}{*}{$P S$} & $0.008 * * *$ & $0.008 * * *$ & $0.009 * * *$ & $0.007 * * *$ & 0.020 & $0.007 * * *$ \\
\hline & $(0.002)$ & $(0.002)$ & $(0.002)$ & $(0.002)$ & $(0.017)$ & $(0.002)$ \\
\hline \multicolumn{7}{|l|}{ Institutional } \\
\hline \multirow[t]{2}{*}{ Ownership } & -0.004 & -0.003 & -0.008 & -0.010 & -0.023 & 0.000 \\
\hline & $(0.013)$ & $(0.013)$ & $(0.013)$ & $(0.013)$ & $(0.015)$ & $(0.013)$ \\
\hline \multirow[t]{2}{*}{ Number of Analysts } & -0.000 & -0.000 & -0.000 & -0.000 & 0.000 & -0.000 \\
\hline & $(0.000)$ & $(0.000)$ & $(0.000)$ & $(0.000)$ & $(0.000)$ & $(0.000)$ \\
\hline Wald Test & $615.0 * * *$ & $620.3 * * *$ & $661.4 * * *$ & $630.4 * * *$ & $610.8 * * *$ & $610.3 * * *$ \\
\hline AR(1) p-value & 0.645 & 0.490 & 0.554 & 0.575 & 0.770 & 0.378 \\
\hline Hansen test $p$-value & 1 & 1 & 1 & 1 & 0.440 & 1 \\
\hline Observations & 70,082 & 70,082 & 70,082 & 70,063 & 16,587 & 53,495 \\
\hline Number of panels & 3,494 & 3,494 & 3,494 & 3,494 & 1,237 & 3,049 \\
\hline
\end{tabular}

This table presents the regressions of option volatility and the dependent variable is VSPREAD, which is the volatility spread that measures the difference between the implied volatility of a put option and its corresponding call option matched on strike price and maturity date. $R M_{-} P R O D$ represents abnormal production costs; $R M_{-} D I S X$ represents abnormal discretionary expenditure; $R M$ is the sum of $R M_{-} P R O D$ and $R M_{-} D I S X$; and $U_{-} R M$ represents unexpected real earnings management. $A M$ represents accruals management. $\operatorname{SHINT}_{i, t}$ is the average monthly short interest of firm $i$ in quarter $t$. PIN Pi,t $_{\text {is }}$ is probability of informed trading. Illiquidity $y_{i, t}$ is the daily ratio of absolute stock $i$ return to its dollar volume, averaged over a year ending one month prior to quarter $t . L M C_{i, t}$ represents the natural logarithm of market capitalization of firm $i$ in quarter $t . C S_{i, t}$ and $P S_{i, t}$ are the average proportional bid-ask spreads of calls and puts, respectively. Institutional ownership represents the percentage of the shares outstanding held by institutional owners as reported in the Thomson Financial database. The number of analysts is obtained from the IBES database. Pre- and post-SOX represent the time periods before and after the passage of the 2002 U.S. Sarbanes-Oxley Act, respectively. $T$-values are presented in parentheses. *, ** and $* * *$ represent significance at the $10 \%, 5 \%$ and $1 \%$ levels, respectively. 
Table 7: GMM Panel Regressions of Volatility Skewness on Real Activities Manipulation

\begin{tabular}{|c|c|c|c|c|c|c|}
\hline \multirow{2}{*}{$\begin{array}{l}\text { Independent } \\
\text { Variables }\end{array}$} & \multicolumn{4}{|c|}{ Full sample } & \multirow[b]{2}{*}{ Pre-SOX } & \multirow[b]{2}{*}{ Post-SOX } \\
\hline & Model 1 & Model 2 & Model 3 & Model 4 & & \\
\hline$V S K E W_{t-1}$ & $\begin{array}{l}0.296 * * * \\
(0.000)\end{array}$ & $\begin{array}{l}0.297 * * * \\
(0.000)\end{array}$ & $\begin{array}{l}0.296 * * * \\
(0.000)\end{array}$ & $\begin{array}{l}0.296 * * * \\
(0.000)\end{array}$ & $\begin{array}{l}0.404 * * * \\
(0.005)\end{array}$ & $\begin{array}{l}0.266^{* * * *} \\
(0.000)\end{array}$ \\
\hline$R M$ & $\begin{array}{l}0.023 * * * \\
(0.000)\end{array}$ & & & & & \\
\hline$R M_{-} P R O D$ & & $\begin{array}{l}0.025 * * * \\
(0.000)\end{array}$ & & & & \\
\hline$R M \_D I S X$ & & & $\begin{array}{l}-0.003 * * * \\
(0.000)\end{array}$ & & & \\
\hline$U_{-} R M$ & & & & $\begin{array}{l}0.002 * * * \\
(0.000)\end{array}$ & $\begin{array}{l}-0.013 * * * \\
(0.001)\end{array}$ & $\begin{array}{l}0.037 * * * \\
(0.000)\end{array}$ \\
\hline$A M$ & & & & $\begin{array}{l}0.006 * * * \\
(0.002)\end{array}$ & $\begin{array}{l}0.081 * * * \\
(0.001)\end{array}$ & $\begin{array}{l}-0.001 \\
(0.001)\end{array}$ \\
\hline SHINT & $\begin{array}{l}0.002 \\
(0.021)\end{array}$ & $\begin{array}{l}0.003 \\
(0.019)\end{array}$ & $\begin{array}{l}0.002 \\
(0.036)\end{array}$ & $\begin{array}{l}0.002 \\
(0.021)\end{array}$ & $\begin{array}{l}0.018 * * * \\
(0.000)\end{array}$ & $\begin{array}{l}0.002 \\
(0.035)\end{array}$ \\
\hline PIN & $\begin{array}{l}0.037 * * * \\
(0.000)\end{array}$ & $\begin{array}{l}0.037 * * * \\
(0.000)\end{array}$ & $\begin{array}{l}0.039 * * * \\
(0.000)\end{array}$ & $\begin{array}{l}0.037 * * * \\
(0.000)\end{array}$ & $\begin{array}{l}0.048 * * * \\
(0.010)\end{array}$ & $\begin{array}{l}0.015 * * * \\
(0.000)\end{array}$ \\
\hline Illiquidity & $\begin{array}{l}-0.092 \\
(0.205)\end{array}$ & $\begin{array}{l}-0.091 \\
(0.271)\end{array}$ & $\begin{array}{l}-0.093 \\
(0.264)\end{array}$ & $\begin{array}{l}-0.089 \\
(0.201)\end{array}$ & $\begin{array}{l}0.106 \\
(0.120)\end{array}$ & $\begin{array}{l}-0.195 \\
(0.295)\end{array}$ \\
\hline$L M C$ & $\begin{array}{l}-0.005^{* * *} \\
(0.000)\end{array}$ & $\begin{array}{l}-0.005^{* * *} \\
(0.000)\end{array}$ & $\begin{array}{l}-0.005^{* * *} \\
(0.000)\end{array}$ & $\begin{array}{l}-0.005^{* * *} \\
(0.000)\end{array}$ & $\begin{array}{l}0.002 * * * \\
(0.000)\end{array}$ & $\begin{array}{l}-0.005 * * * \\
(0.000)\end{array}$ \\
\hline CS & $\begin{array}{l}-0.015 \\
(0.019)\end{array}$ & $\begin{array}{l}-0.015 \\
(0.019)\end{array}$ & $\begin{array}{l}-0.015 \\
(0.018)\end{array}$ & $\begin{array}{l}-0.016 \\
(0.024)\end{array}$ & $\begin{array}{l}-0.085 \\
(0.076)\end{array}$ & $\begin{array}{l}-0.020 \\
(0.020)\end{array}$ \\
\hline$P S$ & $\begin{array}{l}0.022 * * * \\
(0.000)\end{array}$ & $\begin{array}{l}0.022 * * * \\
(0.000)\end{array}$ & $\begin{array}{l}0.022 * * * \\
(0.000)\end{array}$ & $\begin{array}{l}0.022 * * * \\
(0.000)\end{array}$ & $\begin{array}{l}0.033 * * * \\
(0.002)\end{array}$ & $\begin{array}{l}0.024 * * * \\
(0.000)\end{array}$ \\
\hline Institutional & & & & & & \\
\hline Ownership & $\begin{array}{l}-0.015 \\
(0.042)\end{array}$ & $\begin{array}{l}-0.015 \\
(0.042)\end{array}$ & $\begin{array}{l}-0.015 \\
(0.041)\end{array}$ & $\begin{array}{l}-0.015 \\
(0.041)\end{array}$ & $\begin{array}{l}-0.012 \\
(0.042)\end{array}$ & $\begin{array}{l}0.001 \\
(0.023)\end{array}$ \\
\hline Number of Analysts & $\begin{array}{l}-0.001 \\
(0.000)\end{array}$ & $\begin{array}{l}-0.001 \\
(0.000)\end{array}$ & $\begin{array}{l}-0.001 \\
(0.000)\end{array}$ & $\begin{array}{l}-0.001 \\
(0.000)\end{array}$ & $\begin{array}{l}-0.000 \\
(0.000)\end{array}$ & $\begin{array}{l}-0.001 \\
(0.000)\end{array}$ \\
\hline Wald Test & 428 & 485 & 1020 & 476 & 1166 & 1010 \\
\hline $\mathrm{AR}(1) \mathrm{p}$-value & 0.177 & 0.210 & 0.166 & 0.173 & 0.344 & 0.497 \\
\hline Hansen test $p$-value & 1 & 1 & 1 & 1 & 0.446 & 1 \\
\hline Observations & 70,082 & 70,082 & 70,082 & 70,063 & 16,587 & 53,495 \\
\hline Number of panels & 3,494 & 3,494 & 3,494 & 3,494 & 1,237 & 3,049 \\
\hline
\end{tabular}

This table presents the regressions of option volatility and the dependent variable is VSKEW, which is the difference in implied volatility between out-of-the-money put options and at-the-money call options. $R M_{-} P R O D$ represents abnormal production costs; $R M_{-} D I S X$ represents abnormal discretionary expenditure; $R M$ is the sum of $R M_{-} P R O D$ and $R M_{-} D I S X$; and $U_{-} R M$ represents unexpected real earnings management. $A M$ represents accruals management. $S H I N T_{i, t}$ is the average monthly short interest of firm $i$ in quarter $t$. PIN $N_{i, t}$ is the probability of informed trading. Illiquidity $y_{i, t}$ is the daily ratio of absolute stock $i$ return to its dollar volume, averaged over a year ending one month prior to quarter $t . L M C_{i, t}$ represents the natural logarithm of market capitalization of firm $i$ in quarter $t . C S_{i, t}$ and $P S_{i, t}$ are the average proportional bid-ask spreads of calls and puts, respectively. Institutional ownership represents the percentage of the shares outstanding held by institutional owners as reported in the Thomson Financial database. The number of analysts is obtained from the IBES database. Pre- and post-SOX represent the time periods before and after the passage of the 2002 U.S. Sarbanes-Oxley Act, respectively. $T$-values are presented in parentheses. *,** and *** represent significance at the $10 \%, 5 \%$ and $1 \%$ levels, respectively. 
Table 8: Three-Stage Least Squares Regressions of Volatility Spread, Volatility Skewness and Short Interest

\begin{tabular}{|c|c|c|c|c|}
\hline VARIABLES & $\begin{array}{l}\text { Model 1 } \\
\text { Equation 1: } \\
\text { VSPREAD }\end{array}$ & $\begin{array}{l}\text { Equation 2: } \\
\text { SHINT }\end{array}$ & $\begin{array}{l}\text { Model } 2 \\
\text { Equation 1: } \\
\text { VSSKEW }\end{array}$ & $\begin{array}{l}\text { Equation 2: } \\
\text { SHINT }\end{array}$ \\
\hline Constant & $\begin{array}{l}-0.006 \\
(0.005)\end{array}$ & $\begin{array}{l}0.145^{* * *} \\
(0.027)\end{array}$ & $\begin{array}{l}-0.138^{* * *} \\
(0.017)\end{array}$ & $\begin{array}{l}0.299 * * * \\
(0.024)\end{array}$ \\
\hline$U_{-} R M$ & $\begin{array}{l}0.002 * * * \\
(0.000)\end{array}$ & $\begin{array}{l}-0.017 * * * \\
(0.003)\end{array}$ & $\begin{array}{l}0.008 * * * \\
(0.002)\end{array}$ & $\begin{array}{l}-0.015^{* * * *} \\
(0.003)\end{array}$ \\
\hline$A M$ & $\begin{array}{l}0.002 * * * \\
(0.000)\end{array}$ & $\begin{array}{l}0.024 * * * \\
(0.003)\end{array}$ & $\begin{array}{l}0.010^{* * *} \\
(0.002)\end{array}$ & $\begin{array}{l}0.022 * * * \\
(0.003)\end{array}$ \\
\hline SHINT & $\begin{array}{l}0.090^{* * *} \\
(0.007)\end{array}$ & & $\begin{array}{l}0.488^{* * *} \\
(0.019)\end{array}$ & \\
\hline VSPREAD & & $\begin{array}{l}5.558 * * * \\
(0.471)\end{array}$ & & $\begin{array}{l}1.478 * * * \\
(0.034)\end{array}$ \\
\hline PIN & $\begin{array}{l}0.007 * * \\
(0.003)\end{array}$ & & $\begin{array}{l}0.031 * * \\
(0.013)\end{array}$ & \\
\hline$I R$ & $\begin{array}{l}0.033 * * * \\
(0.004)\end{array}$ & $\begin{array}{l}-0.358^{* * * *} \\
(0.030)\end{array}$ & $\begin{array}{l}0.142 * * * \\
(0.015)\end{array}$ & $\begin{array}{l}-0.324 * * * \\
(0.027)\end{array}$ \\
\hline$L M C$ & $\begin{array}{l}-0.002 * * * \\
(0.000)\end{array}$ & $\begin{array}{l}-0.029 * * * \\
(0.002)\end{array}$ & $\begin{array}{l}-0.018^{* * *} \\
(0.001)\end{array}$ & $\begin{array}{l}-0.039 * * * \\
(0.002)\end{array}$ \\
\hline CS & $\begin{array}{l}-0.009 * * * \\
(0.001)\end{array}$ & & $\begin{array}{l}-0.001 \\
(0.003)\end{array}$ & \\
\hline$P S$ & $\begin{array}{l}0.009 * * * \\
(0.001)\end{array}$ & & $\begin{array}{l}0.009 * * * \\
(0.002)\end{array}$ & \\
\hline$B M$ & & $\begin{array}{l}-0.015^{* * *} \\
(0.003)\end{array}$ & & $\begin{array}{l}-0.008^{* * * *} \\
(0.001)\end{array}$ \\
\hline$R$ & & $\begin{array}{l}-0.012 \\
(0.011)\end{array}$ & & $\begin{array}{l}0.008 \\
(0.006)\end{array}$ \\
\hline$V R$ & & $\begin{array}{l}1.629 * * * \\
(0.239)\end{array}$ & & $\begin{array}{l}0.382 * * * \\
(0.098)\end{array}$ \\
\hline Leverage & & $\begin{array}{l}0.029 * * * \\
(0.005)\end{array}$ & & $\begin{array}{l}0.010 * * * \\
(0.002)\end{array}$ \\
\hline Institutional Ownership & $\begin{array}{l}-0.017 \\
(0.012)\end{array}$ & $\begin{array}{l}0.141 * * * \\
(0.009)\end{array}$ & $\begin{array}{l}-0.041 \\
(0.034)\end{array}$ & $\begin{array}{l}0.090 * * * \\
(0.007)\end{array}$ \\
\hline Number of Analysts & $\begin{array}{l}-0.000 \\
(0.000)\end{array}$ & $\begin{array}{l}0.001 * * * \\
(0.000)\end{array}$ & $\begin{array}{l}-0.001 \\
(0.011)\end{array}$ & $\begin{array}{l}0.001 * * * \\
(0.000)\end{array}$ \\
\hline $\begin{array}{l}\text { Overall R-squared } \\
\text { Year fixed effects } \\
\text { Observations }\end{array}$ & $\begin{array}{l}0.130 \\
\text { Yes } \\
68,590\end{array}$ & 68,590 & $\begin{array}{l}0.115 \\
\text { Yes } \\
68,590\end{array}$ & 68,590 \\
\hline
\end{tabular}

This table presents the regression results of a system of structural equations using three-stage least squares models. VSPREAD is the volatility spread that measures the difference between the implied volatility of a put option and its corresponding call option matched on strike price and maturity date. SHINT $T_{i, t}$ is the average monthly short interest of firm $i$ in quarter $t$. VSKEW is volatility skew calculated as the implied volatility of the OTM put option minus the implied volatility of the ATM call option. URM is the unexpected total real earnings management for firm $i$ quarter $t-1 . B M_{i, t}$ is the book-to-market ratio calculated as the common value of equity divided by market capitalization. $R_{i, t}$ is the monthly return over the window $(-12,-2)$ about quarter $t . V R_{i, t}$ is the standard deviation of the market model residuals using daily returns over a one-year window ending one month prior to quarter $t$. $D E B T_{i, t}$ is the ratio of total liabilities to total assets. $P I N_{i, t}, I R_{i, t}, L M C_{i, t}, C S_{i, t}$, and $P S_{i, t}$ are control variables that can affect the level of option volatilities (Atilgan 2014). PIN $N_{i, t}$ is the probability of informed trade computed by Venter and De Jongh (2006) as a proxy of information asymmetry. The PIN database is available from Professor Stephen Brown's website. ILiq $q_{i, t}$ is the illiquidity ratio calculated as the average ratio of the daily absolute return to the dollar trading volume on that day over a one-year window ending one month prior to the quarter $t . L M C_{i, t}$ is the natural logarithm of market capitalization of firm $i$ in period $t . C S_{i, t}$ and $P S_{i, t}$ are the average proportional bid-ask spreads of calls and puts, respectively. $I N S T_{\mathrm{i}, \mathrm{t}}$ is the percentage of the firm shares held by institutional owners. ANALYSTS $\mathrm{i}, \mathrm{t}$ is the number of analysts following the firm. Robust standard errors are presented in parentheses. *, ** and $* * *$ represent significance at the $10 \%, 5 \%$ and $1 \%$ levels, respectively. 